\title{
Article \\ MCH-R1 Antagonist GPS18169, a Pseudopeptide, Is a Peripheral Anti-Obesity Agent in Mice
}

\author{
Jean A. Boutin ${ }^{1, *}++^{\mathbb{D}}$, Magali Jullian ${ }^{2}$, Lukasz Frankiewicz ${ }^{2,}$, Mathieu Galibert $^{2}$, Philippe Gloanec ${ }^{3}$, \\ Thierry Le Diguarher ${ }^{4}$, Philippe Dupuis ${ }^{5}$, Amber Ko ${ }^{6}$, Laurent Ripoll ${ }^{1}$, Marc Bertrand ${ }^{4}$, Anne Pecquery ${ }^{5}$, \\ Gilles Ferry ${ }^{7}$ and Karine Puget ${ }^{2}$
}

check for updates

Citation: Boutin, J.A.; Jullian, M.; Frankiewicz, L.; Galibert, M.; Gloanec, P.; Le Diguarher, T.; Dupuis, P.; Ko, A.; Ripoll, L.; Bertrand, M.; et al. MCH-R1 Antagonist GPS18169, a Pseudopeptide, Is a Peripheral Anti-Obesity Agent in Mice. Molecules 2021, 26, 1291. https://doi.org/ 10.3390/molecules26051291

Academic Editor: Billy KC Chow

Received: 3 February 2021

Accepted: 22 February 2021

Published: 27 February 2021

Publisher's Note: MDPI stays neutral with regard to jurisdictional claims in published maps and institutional affiliations.

Copyright: (c) 2021 by the authors. Licensee MDPI, Basel, Switzerland. This article is an open access article distributed under the terms and conditions of the Creative Commons Attribution (CC BY) license (https:// creativecommons.org/licenses/by/ $4.0 /)$.
1 Institut de Recherches Internationales Servier, 92284 Suresnes, France; laurent.ripoll@servier.com

2 Genepep SA, 34430 Saint Jean de Vedas, France; magali.jullian@genepep.com (M.J.); 1.frankiewicz@pracowniacms.pl (L.F.); mathieu.galibert@genepep.com (M.G.); karine.puget@genepep.com (K.P.)

3 Institut de Recherches Servier, 92150 Suresnes, France; phgloanec@gmail.com

4 Technologie Servier, 45520 Gidy, France; thierry.le-diguarher@servier.com (T.L.D.); m.bertrand@servier.com (M.B.)

5 Eurofins Discovery, 86600 Celle l'Evescault, France; PhilippeDupuis@eurofins.com (P.D.); AnnePecquery@eurofins.com (A.P.)

6 Eurofins Discovery, New Taipei City 24891, Taiwan; AmberKo@eurofins.com

7 Institut de Recherches Servier, 78290 Croissy-sur-Seine, France; gilles.ferry@servier.com

* Correspondence: ja.boutin.pro@gmail.com

+ Current affiliation: PHARMADEV (Pharmacochimie et biologie pour le développement), Faculté de Pharmacie, 31000 Toulouse, France.

$\ddagger$ Current affiliation: Gyros Protein Technologies AB, 75183 Uppsala, Sweden.

Abstract: Melanin-concentrating hormone $(\mathrm{MCH})$ is a 19 amino acid long peptide found in the brain of animals, including fishes, batrachians, and mammals. $\mathrm{MCH}$ is implicated in appetite and/or energy homeostasis. Antagonists at its receptor (MCH-R1) could be major tools (or ultimately drugs) to understand the mechanism of $\mathrm{MCH}$ action and to fight the obesity syndrome that is a worldwide societal health problem. Ever since the deorphanisation of the $\mathrm{MCH}$ receptor, we cloned, expressed, and characterized the receptor MCH-R1 and started a vast medicinal chemistry program aiming at the discovery of such usable compounds. In the present final work, we describe GPS18169, a pseudopeptide antagonist at the MCH-R1 receptor with an affinity in the nanomolar range and a Ki for its antagonistic effect in the 20 picomolar range. Its metabolic stability is rather ameliorated compared to its initial parent compound, the antagonist S38151. We tested it in an in vivo experiment using high diet mice. GPS18169 was found to be active in limiting the accumulation of adipose tissues and, correlatively, we observed a normalization of the insulin level in the treated animals, while no change in food or water consumption was observed.

Keywords: diet-induced obesity; $\mathrm{MCH}$; $\mathrm{MCH}-\mathrm{R} 1$ antagonist; pseudopeptide; treatment

\section{Introduction}

Obesity is a major societal and health problem, in western countries and beyond [1-3]. We recently saw how obesity and its complications as a co-morbidity factor [4] might threaten the health of many people in front of viral aggression [5], rendering this condition even more dangerous than "simply" those traditionally associated with overweight conditions, such as heart conditions and joint and bone fragilization, among many others. For about two decades, researchers have attempted to determine the role of several central systems in appetite control, reasoning that the smaller the food income, the smaller the weight gain, and thus the better the health condition will be. Unsuccessful attempts are too numerous to list, but one can cite neuropeptides 1 and 5, orexin, and melanin-concentrating hormone $(\mathrm{MCH})$ including upstream works from our group. 
One of those systems, $\mathrm{MCH}$, attracted our attention because it was described as a central control of food intake and energy expenditure [6]. $\mathrm{MCH}$ is a rather small peptide that exists in many animals from fishes to mammals in a quite conserved sequence [7,8]. It is produced in the brain in a well-understood fashion and circulates at low concentrations in mammal blood. It mainly exerts its activity through a seven transmembrane domain receptor named MCH-R1. The molecular pharmacology of this peptide and its receptor has been explored thoroughly during the two last decades, and its implication in appetite control has been reported several times (see details in Audinot et al. [9]). For example, engineered mice with either the receptor or the hormone knockouts were lean, even under access to a Western cafeteria regimen [10-12]. Moreover, in hypothalamic neurons, $\mathrm{MCH}-$ $\mathrm{R} 1$ has been located in the primary cilium of the cell. In the rare Bardet Biedl syndrome, there is a defect in the assembly of the primary cilium in hypothalamic neurons and, consequently, there is ectopic activation of the MCH-R1 signaling pathway, leading to hyperphagia and a decrease in satiety responsible for obesity and being overweight in affected children [13,14]. Furthermore, outside the obesity area, MCH-R1 antagonists may help us understand the interrelation between $\mathrm{MCH}$ and cocaine addiction [15], Alzheimerrelated memory loss [16], depression [17] and sleep [18], as well as its interplay with other central systems such as the GABAergic one [19].

High-throughput screening campaigns for antagonists at this receptor, mostly using small molecules, were reported with mixed successes [20-22]. For example, at the hit-tolead stage, it was almost impossible to separate the chemical feature, leading to high affinity at MCH-R1 from those leading to a strong inhibition of the hErg channel $[23,24]$ and its associated cardiac toxicity, a feature unacceptable at this stage of discovery/development of new anti-obesity drug candidates. Furthermore, the behavior of animals after treatment with some of those drug candidates strongly suggested that $\mathrm{MCH}$ was centrally involved in far more than appetite regulation or that small organic molecules (as opposed to peptides) were not specific enough of the MCH system. Those premises were recently confirmed by the evidence linking sleep and the circadian rhythm to $\mathrm{MCH}$ neurons as well as rapid eye movement (REM) in narcolepsy [25]. These observations led to a decrease in interest in the $\mathrm{MCH}$ system.

We walked a different line of research, reasoning that it was possible to find peptide analogues with interesting pharmacological characteristics. By intensively studying and modifying the hormone peptide sequence, we ended up with peptides or pseudopeptides presenting several interesting features from a peptide super agonist [26], to a radioligand, S36057 [27] and a powerful antagonist, S38151 [28,29]. S38151 had an affinity at the human $\mathrm{MCH}-\mathrm{R} 1$ receptor in the low nanomolar range and was an antagonist. Furthermore, despite limited biostability in animals, as adjudged from its concentration in blood, it showed small activity in vivo in all the obesity models [29]. We anticipated that the main reason for the blood instability of the cyclic pseudopeptide S38151 was due to its fragile S-S bond. Thus, we tried to ameliorate the stability of the cyclisation by using alternative solutions to the S-S bond: a lactam bridge or a click chemistry-based triazole bridge despite its penta-atomic cycle feature in the middle of the bridge. We also noted that the number of atoms forming the peptide cycle was an important feature of the structure-activity relationship. In the present work, we describe various avenues we walked to render the pseudopeptides more stable, as well as still being able to bind to the human receptor with high affinity. Choosing among the most powerful ones, we moved to stability studies, with the intention to fully understand the compounds in comparison to previous results obtained with their more natural counterpart, S38151 [29]. Once we were convinced that GPS18169 was able to circulate without major and immediate loss, and with potentially minimal penetration into brain tissues, we tested it in the classical model of diet-induced obesity. GPS18169 successfully fulfilled the initial goal: a slight decrease in body weight with a return to almost normal insulin level. 


\section{Results}

For several years, a trend to use peptides as tools [30] as well as pharmacological or therapeutic agents has risen again [31-33]. Despite a bad reputation, peptides tend to be better complementary tools to proteins than organic molecules could be. Some beautiful successes have been reported in the literature, as peptide drugs [34] and more and more techniques, including modifications of the peptide structures, were described (see discussion in Boutin et al. [35]).

\subsection{Peptide Design, Syntheses, and Characterization}

The main problem encountered in the $\mathrm{MCH}$ receptor (MCH-R1) molecular pharmacology has been the stability of the compound in in vivo situations [29]. Despite this apparent lack of stability, the potent MCH-R1 antagonist, S38151, showed interesting characteristics in all the tested obesity models [29]. The main weakness of this compound was its disulfide bridge, which potentially lacks in vivo stability. We thus concentrated our effort in exploring several alternatives to the S-S bridge by trying the three following bridge substitutes: an alkyl chain bridge, a lactam bridge and a triazole bridge. It turned out that the synthetic difficulties rendered the access to alkyl chain-substituted pseudopeptides almost impossible during the time frame of the project to obtain candidates in a fair amount and/or in fair purity, compatible with further pharmacological explorations. Thus, only the lactam and the triazole bridges were explored and exemplified herein. Nevertheless, many difficulties linked to the solid phase synthesis strategies had to be overcome. Beside some more S-S bridge containing peptides, two series of pseudopeptides were obtained with potentially higher stability in biological milieus. These various pseudopeptides, analogues of the S38151 antagonist, were obtained in a sufficient amount, permitting them to be considered in a series of biological characterizations. Their sequences and main purity characteristics are shown in Table S1.

\subsection{Peptide Molecular Pharmacology}

As in the past, our strategy was to measure the affinity of the peptides at the human MCH-R1 utilizing a classical binding assay [26]. The goal was to progress through various synthetic strategies until a low nanomolar compound was obtained. The antagonistic potential of these compounds was then evaluated. Due to the antagonism of S38151, it was expected that this antagonism remained in the newly synthesized pseudopeptides. Examples of the lactam and triazole bridges are given in Figure 1 to help the reader to visualize the different constructs.

\subsubsection{S-S Bridge Bearing Pseudopeptides}

While the data were obtained simultaneously, we chose to present our progress by showing, first, the data for pseudopeptides bearing an S-S bond, as in the natural hormone as well as in our reference compound, S38151. The data are gathered in Table 1. Although we believed that the main problem would be the stability of the compound (see below), we made little progress in this series because only by changing Arg into hArg we found a slightly better candidate, based on its affinity at the $\mathrm{MCH}$ receptor.

\subsubsection{Lactam Bridge Bearing Pseudopeptides}

At the same time, we explored the possibility of substituting the S-S bridge with a lactam one. This was performed by incorporating in position " 2 " an amino acid bearing a $\mathrm{COOH}$ or an $\mathrm{NH} 2$ at the end of their side chain, while the opposite was performed at position " 11 ". Note that the numbering is based on the natural sequence of the human $\mathrm{MCH}$ peptide $(\mathrm{hMCH})$, even though amino acids were sometimes suppressed from the peptide sequences [26]. The data are shown in Table 2. As can be seen, a considerable number of analogues have been synthesized and characterized (71 different structures were studied). Incidentally, the linear peptides (e.g., GPS13670) were poor binders at the $\mathrm{hMCH}$ receptor. We tested a series of couples, including Asp or Glu for the acidic ones 
and Dap, Orn or Lys for the basic ones. We also, in some cases, tested the direction of the $\mathrm{CO}-\mathrm{NH}$ moiety by including some NH-CO bridges (exchanging the acidic amino acids at position 2 by basic amino acids and vice versa). A handful of compounds (GPS13684, GPS13680, GPS13673, GPS12744, GPS13663, GPS13689, GPS15288, GPS13675, GPS13682 and GPS13683) presented sub-nanomolar affinities at the receptor.

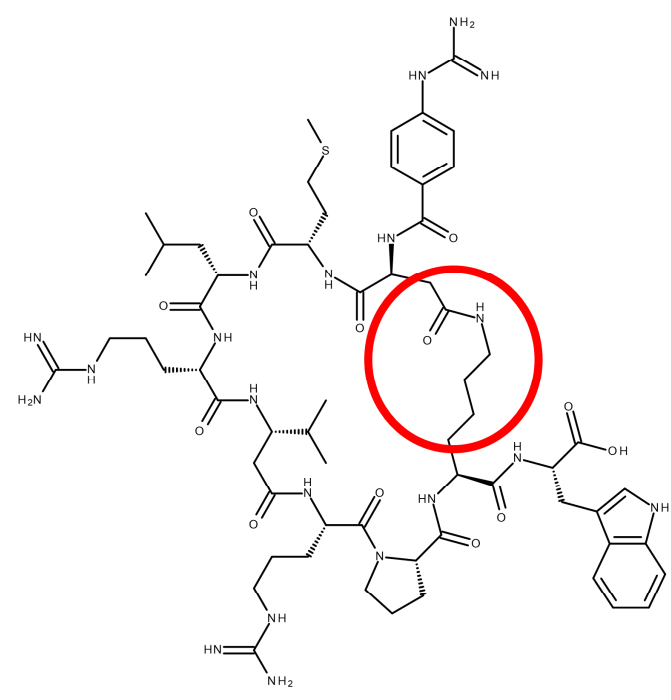

GPS12731

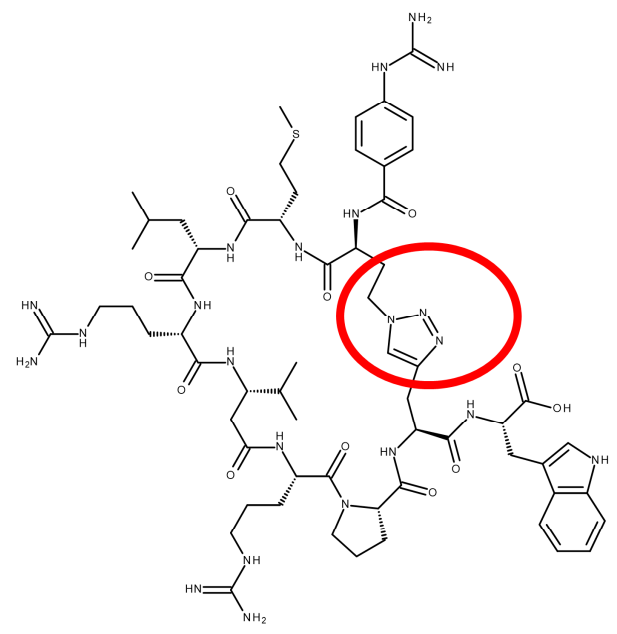

GPS15290

Figure 1. Two structures of peptides representative of the families bearing either a lactam bridge (GPS12731) or a triazole bridge (GPS15290). The lactam bridge was built between a glutamic acid (or aspartic acid for other pseudopeptides) and ornithine (or a lysine) side chains. The triazole bridge was synthesized between an azido-homoalanine and a homopropargylglycine. The red circles point at the bridge structure.

Table 1. Binding affinities at human melanin-concentrating hormone (MCH) receptor of pseudopeptides derived from S38151, bearing an S-S bridge.

\begin{tabular}{|c|c|c|c|c|c|c|c|c|c|c|c|c|c|c|}
\hline \multirow[t]{2}{*}{ Code } & \multicolumn{12}{|c|}{ Sequence } & \multirow[t]{2}{*}{$\mathrm{Km}(\mathrm{nM})$ * } & \multirow[t]{2}{*}{$\mathbf{n}^{\prime}$} \\
\hline & 1 & 2 & 3 & 4 & 5 & 6 & 7 & 8 & 9 & 10 & 11 & 12 & & \\
\hline S38151 (**) & Gua & Cys & Met & Leu & - & Arg & Val & Tyr & Arg & Pro & Cys & $\operatorname{Trp}$ & 4,3 & 29 \\
\hline GPS11371 & Gua & Cys & Met & Leu & - & Arg & - & Tyr & Arg & Pro & Cys & $\operatorname{Trp}$ & $\sim 100$ & 26 \\
\hline GPS11372 & Arg & Cys & Met & Leu & - & Arg & - & Tyr & Arg & Pro & Cys & Trp & $>10,000$ & 26 \\
\hline GPS11373 & Gua & Cys & Met & Leu & - & Arg & Val & - & Arg & Pro & Cys & $\operatorname{Trp}$ & 100 & 26 \\
\hline GPS11374 & Gua & Cys & Met & Leu & - & Arg & Val & Tyr & hArg & Pro & Cys & Trp & 3 & 29 \\
\hline GPS11375 & Gua & Cys & Met & Leu & - & Arg & Val & Tyr & arg & Pro & Cys & Trp & 17 & 29 \\
\hline GPS11376 & Gua & Cys & Met & Leu & - & Arg & Val & Ala & hArg & Pro & Cys & $\operatorname{Trp}$ & $\sim 100$ & 29 \\
\hline GPS11377 & Gua & Cys & Met & Leu & - & - & Val & Tyr & Arg & Pro & Cys & Trp & 27 & 26 \\
\hline GPS11378 & Gua & Cys & Met & Leu & - & Ala & Val & Ala & hArg & Pro & Cys & Trp & 18 & 29 \\
\hline GPS11379 & Gua & Cys & Met & Leu & - & Ala & Ala & - & hArg & Pro & Cys & $\operatorname{Trp}$ & 63 & 26 \\
\hline GPS11380 & Gua & Cys & Met & Leu & - & Arg & Val & - & 5-Ava & Pro & Cys & $\operatorname{Trp}$ & $>100$ & 29 \\
\hline GPS11381 & Gua & Cys & Met & Leu & - & Arg & Val & - & $\mathrm{Abu}$ & Pro & Cys & $\operatorname{Trp}$ & 100 & 28 \\
\hline
\end{tabular}

The bridge is between the yellow-colored amino acids. $\left({ }^{*}\right)$. Data were from $2 \times 2$ independent duplicates. If the variation between the results, altogether, was superior to $15 \%$, the experiments were redone. None of the results are outside of those limits. Our internal data base for MCH-R1 binding experiments comprises 550 independent binding experiments over the course of a decade. For each plate of assay the internal control was MCH. $\left.{ }^{* *}\right)$ data of the parent compound. " $\mathbf{n}^{\prime \prime}$ " is the number of heavy atoms in the ring of the peptides comprising the bridge and the backbone of the amino acids between the colored ones. Abbreviations can be found in the legend of Table S1. 
Table 2. Binding affinities at human MCH-R1 of pseudopeptides derived from S38151, bearing a lactam bridge.

\begin{tabular}{|c|c|c|c|c|c|c|c|c|c|c|c|c|c|c|}
\hline \multirow[t]{2}{*}{ Code } & \multicolumn{12}{|c|}{ Sequence } & \multirow[t]{2}{*}{$\underset{\mathbf{n M}}{\mathbf{K m}}$} & \multirow[t]{2}{*}{$\mathbf{n}^{\prime}$} \\
\hline & 1 & 2 & 3 & 4 & 5 & 6 & 7 & 8 & 9 & 10 & 11 & 12 & & \\
\hline S38151 (**) & Gua & Cys & Met & Leu & - & Arg & Val & Tyr & Arg & Pro & Cys & Trp & 4,3 & 29 \\
\hline GPS13684 & Gua & Glu & Met & Leu & - & Arg & Val & - & Arg & 4-NH2-Pro & Orn & $\operatorname{Trp}$ & 0,36 & 29 \\
\hline GPS13680 & Gua & Glu & Met & Leu & - & Arg & Val & - & Me-Arg & Pro & Orn & $\operatorname{Trp}$ & 0,4 & 29 \\
\hline GPS13673 & Gua & Glu & Met & Leu & - & Arg & Val & - & Arg & Pro & Orn & Bta & 0,68 & 29 \\
\hline GPS12744 & Gua & Glu & Met & Leu & - & Arg & Val & - & Arg & Pro & Orn & Trp & 0,75 & 29 \\
\hline GPS13663 & Gua & Glu & Ethionine & Leu & - & Arg & Val & - & Arg & Pro & Orn & Trp & 0,75 & 29 \\
\hline GPS13689 & Gua & Glu & Met & Leu & & Arg & Val & & Arg & Pro & Orn & Tryptamide & 0,87 & 29 \\
\hline GPS15288 & Gua & Glu & Met & Leu & - & Arg & Val & Tyr & Arg & 4-NH2-Pro & Orn & $\operatorname{Trp}$ & 0,91 & 32 \\
\hline GPS13675 & Gua & Glu & Met & Leu & - & Me-Arg & Val & - & Arg & Pro & Orn & Trp & 0,95 & 29 \\
\hline GPS13682 & Gua & Glu & Met & Leu & - & Arg & Val & - & hArg & Pro & Orn & Trp & 1 & 29 \\
\hline GPS13665 & Gua & Glu & Se-Met & Leu & - & Arg & Val & - & Arg & Pro & Orn & $\operatorname{Trp}$ & 1,2 & 29 \\
\hline GPS14509 & Gua & Glu & Se-Met & F3-Leu & - & Arg & Val & - & Arg & Pro & Orn & Trp & 1,2 & 29 \\
\hline GPS13686 & Gua & Glu & Met & Leu & - & Arg & Val & - & Arg & 4-CF3-Pro & Orn & Trp & 1,3 & 29 \\
\hline GPS13687 & Gua & Glu & Met & Leu & - & Arg & Val & - & Arg & 4-Ph-Pro & Orn & Trp & 1,3 & 29 \\
\hline GPS13677 & Gua & Glu & Met & Leu & - & hArg & Val & - & Arg & Pro & Orn & $\operatorname{Trp}$ & 1,6 & 29 \\
\hline GPS14511 & Gua & Glu & Met & Leu & - & Me-Arg & Val & - & Me-Arg & Pro & Orn & Trp & 1,8 & 29 \\
\hline GPS13679 & Gua & Glu & Met & Leu & - & Arg & Val & - & NO-Arg & Pro & Orn & Trp & 1,9 & 29 \\
\hline GPS13667 & Gua & Glu & Met & Nle & - & Arg & Val & - & Arg & Pro & Orn & Trp & 2 & 29 \\
\hline GPS13674 & Gua & Glu & Met & Leu & - & NO-Arg & Val & - & Arg & Pro & Orn & Trp & 2 & 29 \\
\hline GPS13695 & Gua & Glu & Met & Leu & - & Arg & Val & Tyr & Arg & Pro & Orn & $\operatorname{Trp}$ & 2,2 & 32 \\
\hline GPS13666 & Gua & Glu & Met & F3-Leu & - & Arg & Val & - & Arg & Pro & Orn & Trp & 3 & 29 \\
\hline GPS13678 & Gua & Glu & Met & Leu & - & Cav & Val & - & Arg & Pro & Orn & Trp & 3 & 29 \\
\hline GPS13672 & Gua & Glu & Met & Leu & - & Arg & Val & - & Arg & Pro & Orn & N-Me-Trp & 3,4 & 29 \\
\hline
\end{tabular}


Table 2. Cont.

\begin{tabular}{|c|c|c|c|c|c|c|c|c|c|c|c|c|c|c|}
\hline \multirow{2}{*}{$\begin{array}{c}\text { Code } \\
\text { GPS15287 }\end{array}$} & \multicolumn{12}{|c|}{ Sequence } & \multirow{2}{*}{$\begin{array}{c}\mathbf{K m} \\
\mathbf{n M}\end{array}$} & \multirow{2}{*}{$\begin{array}{l}\mathbf{n}^{\prime} \\
29\end{array}$} \\
\hline & Gua & Glu & Met & Leu & - & Arg & Val & - & Arg & Aib & Orn & $\operatorname{Trp}$ & & \\
\hline GPS15292 & Gua & Glu & Met & Leu & - & Arg & Val & Tyr & Arg & Pro & Orn & $\operatorname{Trp}$ & 3,5 & 32 \\
\hline GPS13685 & Gua & Glu & Met & Leu & - & Arg & Val & - & Arg & (Me)2-Pro & Orn & $\operatorname{Trp}$ & 3,8 & 29 \\
\hline GPS13681 & Gua & Glu & Met & Leu & - & Arg & Val & - & Cit & Pro & Orn & $\operatorname{Trp}$ & 3,9 & 29 \\
\hline GPS14510 & Gua & Glu & Met & F3-Leu & - & Me-Arg & Val & - & Arg & Pro & Orn & Trp & 4,1 & 29 \\
\hline GPS12733 & Gua & Glu & Met & Leu & - & Arg & Val & - & Arg & Pro & $\mathrm{Dab}$ & $\operatorname{Trp}$ & 5,3 & 28 \\
\hline GPS14512 & Gua & Glu & Met & Leu & - & Arg & Val & - & Me-Arg & Me3-Pro & Orn & $\operatorname{Trp}$ & 5,7 & 29 \\
\hline GPS13676 & Gua & Glu & Met & Leu & - & Cit & Val & - & Arg & Pro & Orn & $\operatorname{Trp}$ & 6 & 29 \\
\hline GPS12739 & Gua & Asp & Se-Met & Leu & - & Arg & Val & - & Arg & Pro & Orn & $\operatorname{Trp}$ & 8,5 & 28 \\
\hline GPS14515 & Aaba & Glu & Met & Leu & - & Arg & Val & - & Arg & Pro & Orn & $\operatorname{Trp}$ & 8,6 & 29 \\
\hline GPS12743 & Gua & Orn & Met & Leu & - & Arg & Val & - & Arg & Pro & Asp & Trp & 9 & 28 \\
\hline GPS12745 & Gua & Orn & Met & Leu & - & Arg & Val & - & Arg & Pro & Glu & $\operatorname{Trp}$ & 13 & 29 \\
\hline GPS12737 & Gua & Asp & Ethionine & Leu & - & Arg & Val & - & Arg & Pro & Orn & $\operatorname{Trp}$ & 23 & 28 \\
\hline GPS13661 & Gua & Glu & CH3-S-Cys & Leu & - & Arg & Val & - & Arg & Pro & Orn & Trp & 26 & 29 \\
\hline GPS13668 & Gua & Glu & Met & tBut-Gly & - & Arg & Val & - & Arg & Pro & Orn & $\operatorname{Trp}$ & 28 & 29 \\
\hline GPS12731 & Gua & Asp & Met & Leu & - & Arg & Val & - & Arg & Pro & Lys & Trp & 41 & 29 \\
\hline $\begin{array}{l}\text { GPS13664- } \\
\left.\text { Peak } 1{ }^{* * * *}\right)\end{array}$ & Gua & Glu & Buthionine & Leu & - & Arg & Val & - & Arg & Pro & Orn & $\operatorname{Trp}$ & 87 & 29 \\
\hline GPS13670 & Gua & Ala & Met & Leu & - & Arg & Val & - & Arg & Pro & Ala & $\operatorname{Trp}$ & 110 & 0 \\
\hline GPS12750 & Gua & Asp & Met & Nle & - & Arg & Val & - & Arg & Pro & Orn & $\operatorname{Trp}$ & 140 & 28 \\
\hline GPS13688 & Gua & Glu & Met & Leu & - & Arg & Val & - & Arg & 4-NH2-Pro & Ala & Trp & 170 & 24 \\
\hline GPS12732 & Gua & Glu & Met & Leu & - & Arg & Val & - & Arg & Pro & Dap & $\operatorname{Trp}$ & 210 & 27 \\
\hline
\end{tabular}


Table 2. Cont.

\begin{tabular}{|c|c|c|c|c|c|c|c|c|c|c|c|c|c|c|}
\hline \multirow{2}{*}{$\begin{array}{c}\text { Code } \\
\text { GPS13669 }\end{array}$} & \multicolumn{12}{|c|}{ Sequence } & \multirow{2}{*}{$\begin{array}{c}\begin{array}{c}\mathbf{K m} \\
\mathbf{n M}\end{array} \\
220 \\
\end{array}$} & \multirow{2}{*}{$\begin{array}{r}\mathbf{n}^{\prime} \\
0\end{array}$} \\
\hline & Gua & Glu & Met & Leu & - & Arg & Val & - & Arg & Pro & Orn & Trp & & \\
\hline GPS14488 & Gua & Glu & Met & Leu & Gly & Arg & Val & - & Arg & Pro & Orn & Trp & 270 & 32 \\
\hline $\begin{array}{c}\text { GPS13664- } \\
\text { Peak } 2 \\
\left({ }^{* *}\right) \\
\end{array}$ & Gua & Glu & Buthionine & Leu & - & Arg & Val & - & Arg & Pro & Orn & $\operatorname{Trp}$ & 330 & 29 \\
\hline GPS11398 & Gua & Asp & Met & Leu & - & Arg & Val & Tyr & Arg & Pro & Dap & Trp & 380 & 29 \\
\hline GPS15293 & $\arg$ & Glu & Met & Leu & - & Arg & Val & - & Arg & Pro & Orn & $\operatorname{Trp}$ & 610 & 29 \\
\hline GPS11401 & Gua & Asp & Met & Leu & - & Arg & Val & - & Arg & Pro & Dab & $\operatorname{Trp}$ & 880 & 27 \\
\hline GPS14489 & Gua & Glu & Met & Leu & - & Arg & Val & - & Cav & Pro & Orn & Trp & 900 & 0 \\
\hline GPS12734 & Gua & Asp & Met & Leu & Gly & Arg & Val & - & Arg & Pro & Orn & Trp & $\sim 10,000$ & 31 \\
\hline GPS12736 & Gua & Asp & $\beta$-hMet & Leu & - & Arg & Val & - & Arg & Pro & Orn & Trp & $\sim 10,000$ & 29 \\
\hline GPS13628 & Gua & Asp & Met & $\begin{array}{l}\text { 4-hydro- } \\
\text { Leu }\end{array}$ & - & Arg & Val & - & Arg & Pro & Orn & $\operatorname{Trp}$ & $\sim 10,000$ & 28 \\
\hline GPS12752 & Gua & Asp & Met & Leu & - & Arg & Val & - & Arg & Aib & Orn & $\operatorname{Trp}$ & $\sim 10,000$ & 28 \\
\hline GPS12749 & Gua & Asp & Met & F3-Leu & - & Arg & Val & - & Arg & Pro & Orn & Trp & $\sim 1000$ & 28 \\
\hline GPS12751 & Gua & Asp & Met & tBut-Gly & - & Arg & Val & - & Arg & Pro & Orn & Trp & $\sim 1000$ & 28 \\
\hline GPS12735 & Gua & Asp & $\begin{array}{c}\text { CH3-S- } \\
\text { Cys }\end{array}$ & Leu & - & Arg & Val & - & Arg & Pro & Orn & $\operatorname{Trp}$ & $\sim 1000$ & 28 \\
\hline GPS12738 & Gua & Asp & Buthionine & Leu & - & Arg & Val & - & Arg & Pro & Orn & Trp & $\sim 10,000$ & 28 \\
\hline GPS11400 & Gua & Asp & Met & Leu & - & Arg & Val & - & Arg & Pro & Dap & Trp & $>10,000$ & 26 \\
\hline GPS11408 & Gua & Asp & Met & Leu & - & - & Ala & Ala & hArg & Pro & Dap & Trp & $>10,000$ & 26 \\
\hline GPS11410 & Gua & Asp & Met & Leu & - & Arg & Val & - & $\mathrm{Abu}$ & Pro & Dap & Trp & $>10,000$ & 28 \\
\hline GPS14522 & Gua & Glu & Met & Leu & - & Arg & & & & & & & $>10,000$ & 0 \\
\hline
\end{tabular}


Table 2. Cont.

\begin{tabular}{|c|c|c|c|c|c|c|c|c|c|c|c|c|c|c|}
\hline \multirow{2}{*}{$\begin{array}{c}\text { Code } \\
\text { GPS11403 }\end{array}$} & \multicolumn{12}{|c|}{ Sequence } & \multirow{2}{*}{$\begin{array}{c}\begin{array}{c}\mathbf{K m} \\
\mathbf{n M}\end{array} \\
>1000\end{array}$} & \multirow{2}{*}{$\begin{array}{l}\mathbf{n}^{\prime} \\
29\end{array}$} \\
\hline & Gua & Asp & Met & Leu & - & Arg & Val & Tyr & hArg & Pro & Dap & $\operatorname{Trp}$ & & \\
\hline GPS11399 & Gua & Asp & Met & Leu & - & Arg & - & Tyr & Arg & Pro & Dap & $\operatorname{Trp}$ & $>10,000$ & 26 \\
\hline GPS11402 & Gua & Asp & Met & Leu & - & Arg & Val & - & Arg & Pro & Orn & $\operatorname{Trp}$ & $>10,000$ & 28 \\
\hline GPS11404 & Gua & Asp & Met & Leu & - & Arg & Val & Tyr & arg & Pro & Dap & $\operatorname{Trp}$ & $>10,000$ & 29 \\
\hline GPS11405 & Gua & Asp & Met & Leu & - & Arg & Val & Ala & hArg & Pro & Dap & $\operatorname{Trp}$ & $>10,000$ & 29 \\
\hline GPS11406 & Gua & Asp & Met & Leu & - & - & Val & Tyr & Arg & Pro & Dap & $\operatorname{Trp}$ & $>10,000$ & 26 \\
\hline GPS14523 & & & & & & & Val & - & Arg & Pro & Orn & $\operatorname{Trp}$ & $>10,000$ & 0 \\
\hline
\end{tabular}

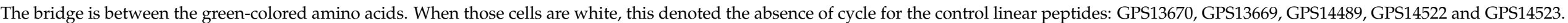

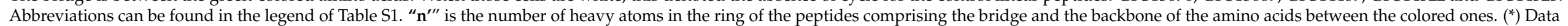

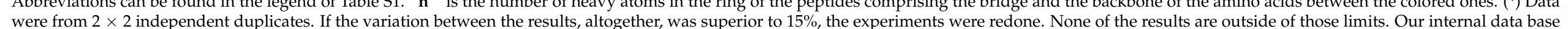

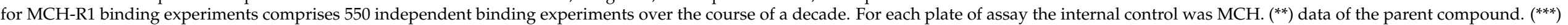
Because buthionine was not optically pure, the two subsequent pseudopeptides were separated, purified, and tested as "peak 1 and peak 2 ". 
Most efforts were put into this series of derivatives because we thought they were easier to obtain and the lactam bridge could lead to better stability. Two criteria directed our efforts: (i) the incorporation of exotic amino acids to enhance the diversity of the pseudopeptides, and (ii) the size of the ring of the cyclic peptides. Once again, the syntheses of several linear analogues demonstrated that the cyclic structure was important for the binding at the receptor. Nevertheless, it was a surprise to find that the linear compounds (GPS13670, GPS13669, GPS14523, GPS14489, and GPS14522) were not completely inactive on the target, although we did not pursue this path further (see, for instance, GPS 13670 and 13669 that bind at the $\mathrm{hMCH}$ with a $\mathrm{Km}$ in the 100 to $200 \mathrm{nM}$ range).

Of note, only two syntheses of the peptides with the "inverse" configuration (acidic chain in position 11 and basic chain in position 2) were attempted: GPS12742 and GPS12745. Because they showed no major differences with their counterparts, further attempts were not performed, and the mainstream strategy remained with the acidic side chain at position 2 and the basic side chain at position 11 . One way to modify or adjust the size of the ring ( $n$ ' being the number of atoms of the ring, see Figure 1) was to use various lengths of side chains in either category: Glu or Asp for acidic ones, and Orn, Lys, Dab or Dap for the basic ones. The goal was to keep the size within the 29 atoms length that seemed to be, with the sole exception of GPS13695 (where $\mathrm{n}^{\prime}$ is 32), the right size to fit the hMCH-R1 topology. Incidentally, attempts were made to crystalize these peptides to gain information on their structure, but these mostly failed. Only one piece of information seems to exist on the structure of MCH-derived peptide (S38151), which we previously described by NMR [28]

\subsubsection{Triazole Bearing Pseudopeptides}

We then moved to a strategy in which we attempted to replace the S-S bridge by a triazole moiety, with the induced change in the general bulkiness of the bridge as compared to the initial disulfide bridge. The data are presented in Table 3. Once again, as we progressed during the various attempts during this exploration, we found very active compounds with affinities at the human receptor at least 10 times superior to S38151. For example, GPS15364 and GPS15366 have Km's in the 200 pM range. Note also that the length of the crown that represents the cyclic pseudopeptide was maintained uniformly in this series at 29 atoms, as in S38151. Of note is also that the orientation of the triazole bridge (whether closer to the Gua terminus or the Trp terminus) seemed to favor an orientation where the triazole was on the Trp side, as can be seen for the three last peptides of Table 3. Linear peptide counterparts showed less potency than their cyclic analogues, as for GPS13683, bearing a canavanine at position 9, that presents an affinity of $1 \mathrm{nM}$ at the receptor, while its linear counterpart, GPS14489 (see Table 2), is 1000 times less potent. 
Table 3. Binding affinities at human MCH-R1 of pseudopeptides derived from S38151, bearing a triazole bridge.

\begin{tabular}{|c|c|c|c|c|c|c|c|c|c|c|c|c|c|c|}
\hline \multirow[t]{2}{*}{ Code } & \multicolumn{12}{|c|}{ Sequence } & \multirow[t]{2}{*}{$\underset{\mathrm{nM}}{\mathbf{K m}}$ * } & \multirow[t]{2}{*}{$\mathbf{n}^{\prime}$} \\
\hline & 1 & 2 & 3 & 4 & 5 & 6 & 7 & 8 & 9 & 10 & 11 & 12 & & \\
\hline S38151 (**) & Gua & Cys & Met & Leu & - & Arg & Val & Tyr & Arg & Pro & Cys & $\operatorname{Trp}$ & 4,3 & 29 \\
\hline GPS14517 & Gua & N3-hAla & Met & Leu & - & Arg & Val & - & Arg & Pro & Propargyl-Gly & $\operatorname{Trp}$ & 2,1 & 29 \\
\hline GPS15290 & Gua & N3-hAla & Met & Leu & - & Arg & bhVal & - & Arg & Pro & Propargyl-Gly & $\operatorname{Trp}$ & 0,86 & 29 \\
\hline GPS15363 & Gua & N3-hAla & Met & Leu & - & Arg & bhVal & - & Arg & Pro & Propargyl-Gly & Bta & 0,3 & 29 \\
\hline GPS15364 & Gua & N3-hAla & Met & Leu & - & Arg & bhVal & - & Arg & 4-NH2-Pro & Propargyl-Gly & $\operatorname{Trp}$ & 0,24 & 29 \\
\hline GPS15365 & Gua & N3-hAla & SeMet & Leu & - & Arg & bhVal & - & Arg & Pro & Propargyl-Gly & $\operatorname{Trp}$ & 0,34 & 29 \\
\hline GPS15366 & Gua & N3-hAla & Met & Leu & - & Arg & bhVal & - & Arg & Pro & Propargyl-Gly & Triptamide & 0,21 & 29 \\
\hline GPS15367 & Gua & N3-hAla & NMeMet & Leu & - & Arg & bhVal & - & Arg & Pro & Propargyl-Gly & $\operatorname{Trp}$ & 670 & 29 \\
\hline GPS15368 & Gua & N3-hAla & Met & NMeLeu & - & Arg & bhVal & - & Arg & Pro & Propargyl-Gly & $\operatorname{Trp}$ & 360 & 29 \\
\hline GPS18169 & Gua & N3-hAla & Nle & Leu & - & Arg & bhVal & - & Arg & Pro & Propargyl-Gly & $\operatorname{Trp}$ & 1,2 & 29 \\
\hline GPS14516 & Gua & Propargyl-Gly & Met & Leu & - & Arg & Val & - & Arg & Pro & N3-hAla & $\operatorname{Trp}$ & 1,9 & 29 \\
\hline GPS14518 & Gua & Propargyl-Gly & Met & Leu & - & Arg & Val & - & Arg & Pro & N3-nVal & $\operatorname{Trp}$ & 1,8 & 29 \\
\hline GPS15291 & Gua & Propargyl-Gly & Ethionine & Leu & - & Arg & bhVal & - & Arg & Pro & N3-hAla & $\operatorname{Trp}$ & 91 & 29 \\
\hline
\end{tabular}

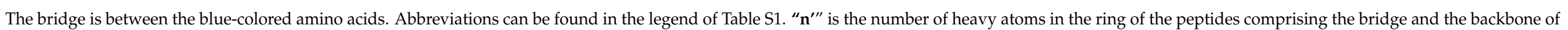

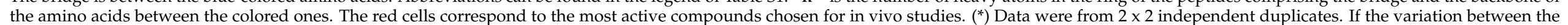

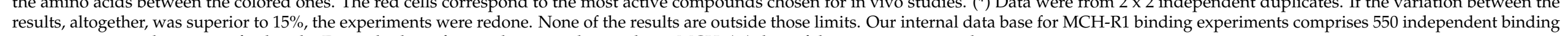
experiments over the course of a decade. For each plate of assay the internal control was MCH. $\left({ }^{* *}\right)$ data of the parent compound. 
According to previous findings, all $\mathrm{MCH}$ analogues deprived of glycine at the position 5 found in the natural hormone were showing antagonistic activities. Indeed, starting at GPS12744, we found potent antagonistic compounds, as summarized in Table 4. Although antagonistic activity was measured on a single test, without considering the possible biasism [36] of the MCH system (as discussed for another receptor system [37,38]), we were confident from our previous knowledge of this receptor, that this antagonism would be translated in a living system like for S38151 [29].

As a conclusion of this section, after having synthesized about 150 peptides, several were found with (i) affinities at the receptor in the nM range and (ii) antagonism in the low pM ranges. Several of them were chosen to enter preliminary metabolic stability tests.

\subsection{Stability of Some of the Pseudopeptides}

Five pseudopeptides were selected to evaluate their stability in plasma from three species: mouse, rat and human. The various peptides were chosen because they represented, considering their internal bridges, the different families that we built, regardless of their performance in the binding assay. Table 5 shows the results. Globally, GPS15290 was the most stable compound. It was cyclized through a triazole bridge, placed between two amino acids incorporated in place of the two cysteines in the original antagonist, S38151, or in the natural hormone hMCH. Under these conditions, all the tested compounds were more stable than the initial antagonist, S38151.

The next step was to study in more detail the in vitro metabolism of the best compound in our hand, GPS15290. A metabolite identification study was then performed on rat and mice hepatocytes. GPS15290 demonstrated mild stability on hepatocytes of both species, although with an initial stage of disappearance probably attributable to the various possibilities of oxidation on the sulfur of the $\mathrm{Met}^{3}$. Metabolite comparative quantification showed some interspecies differences, while the global metabolic pattern observed (Figure 2) appeared to be quite complex.

As the response of the metabolites in tandem mass spectrometry (MS/MS) analytical systems is not known (synthetized metabolites were not available for calibration), the only quantitative comparison possible is between both species for each individual metabolite (expressed here as the relative percentage across species). At least 13 metabolites were measured under these conditions. They could be divided into two different classes: cyclic peptides with or without truncation and oxidation (M6, M8, M9, M17 and M19) and linear peptides because of the hydrolytic ring opening with or without truncation and oxidation (all others). The structure of one metabolite (M11) was not determined. All metabolites were observed in rats and mice except for M13, which was only observed in rats. The unchanged compound was measured at the end of the experiment.

\subsection{From GPS15290 to GPS18169}

As we expected problems with the GPS15290 compound due to the possible various oxidation states of the sulfur of $\mathrm{Met}^{3}$, we decided to also test a close analogue of this compound, GPS18169, in which Met was substituted by Nle. This compound has the same global features as GPS15290: particularly the number of atoms in the ring, and the length of a side chain of Nle compared to Met, but no sulfur in the side chain. As foreseen, the pseudopeptide maintained a nanomolar affinity at the receptor (Table 3) and an antagonistic functionality in the high picomolar range (see Table 4). Figure 3 presents four typical isotherms for both compounds (GPS15290 and GPS18169) in MCH-R1 binding and in cellular functional antagonism experiments. 
Table 4. Functionality of the most active antagonists pseudopeptides at MCH-R1.

\begin{tabular}{|c|c|c|c|c|c|c|c|c|c|c|c|c|c|c|c|}
\hline Code & & & & & & & ence & & & & & & $\begin{array}{c}\mathrm{Km} \\
(\mathrm{nM})\end{array}$ & $\mathbf{n}^{\prime}$ & Ki (pM) \\
\hline S38151 & Gua & Cys & Met & Leu & - & Arg & Val & Tyr & Arg & Pro & Cys & $\operatorname{Trp}$ & 4.3 & 29 & 5000 \\
\hline GPS14517 & Gua & $\mathrm{N}_{3}$-hAla & Met & Leu & - & Arg & Val & - & Arg & Pro & hPra & $\operatorname{Trp}$ & 2.1 & 29 & 22 \\
\hline GPS14518 & Gua & hPra & Met & Leu & - & Arg & Val & - & Arg & Pro & $\mathrm{N}_{3}-\mathrm{nVal}$ & $\operatorname{Trp}$ & 1.8 & 29 & 27 \\
\hline GPS15290 & Gua & $\mathrm{N}_{3}$-hAla & Met & Leu & - & Arg & $\beta$ hVal & - & Arg & Pro & hPra & $\operatorname{Trp}$ & 0.86 & 29 & 28 \\
\hline GPS13695 & Gua & Glu & Met & Leu & - & Arg & Val & Tyr & Arg & Pro & Orn & Trp & 2.2 & 32 & 130 \\
\hline GPS13683 & Gua & Glu & Met & Leu & - & Arg & Val & - & Canava & Pro & Orn & Trp & 1 & 29 & 150 \\
\hline GPS14519 & Gua & $\mathrm{N}_{3}-\mathrm{nVal}$ & Met & Leu & - & Arg & Val & - & Arg & Pro & $\mathrm{hPra}$ & $\operatorname{Trp}$ & 2.3 & 29 & 430 \\
\hline GPS13671 & Gua & hPra & Ethionine & Leu & - & Arg & Val & - & Arg & Pro & $\mathrm{N}_{3}$-hAla & Trp & 120 & 28 & 8000 \\
\hline GPS13670 & Gua & Ala & Met & Leu & - & Arg & Val & - & Arg & Pro & Ala & Trp & 110 & 0 & 30,000 \\
\hline GPS13669 & Gua & Glu & Met & Leu & - & Arg & Val & - & Arg & Pro & Orn & $\operatorname{Trp}$ & 220 & 0 & 300,000 \\
\hline
\end{tabular}

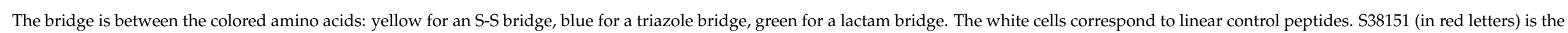

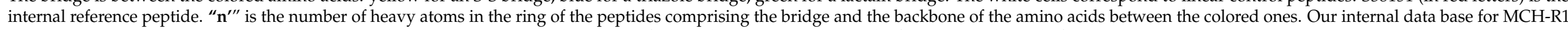
antagonism measurement comprises 300 independent experiments over the course of a decade. Abbreviations can be found in the legend of Table S1. 
Table 5. Plasma stability ( $\mathrm{t}_{1 / 2}$, half-life) of some of the peptides in the series (mouse, rat, human).

\begin{tabular}{ccccccc}
\hline & S38151 & GPS12744 & GPS13663 & GPS13684 & GPS15290 & GPS18169 \\
\hline Mouse & $23 \pm 1.8$ & $26 \pm 3$ & $19 \pm 1$ & $26 \pm 1$ & $173 \pm 9$ & $175 \pm 17$ \\
Rat & $60 \pm 3$ & $143 \pm 12$ & $94 \pm 3$ & $135 \pm 9$ & $300 *$ & $300 *$ \\
Human & $14 \pm 1$ & $300^{*}$ & $300^{*}$ & $300 *$ & $300 *$ & $300 *$ \\
\hline
\end{tabular}

The results are expressed in minutes and are the mean of at least 3 independent experiments. ${ }^{*} 300(5 \mathrm{~h})$ is the maximal time of the experiments. This means that under those conditions, the pseudopeptides were not metabolized at all, and 100\% of the initial dose was found. S38151 is the reference peptide bearing an S-S bridge; GPS12744, GPS13663 and GPS13684 possess a lactam bridge and various substitutions in the sequence; GPS15290 possesses a triazole bridge (see Table S1 for peptide sequences). Because the experiment on GPS18169 was obtained in a separate set of experiments, the results were presented apart from the main table.

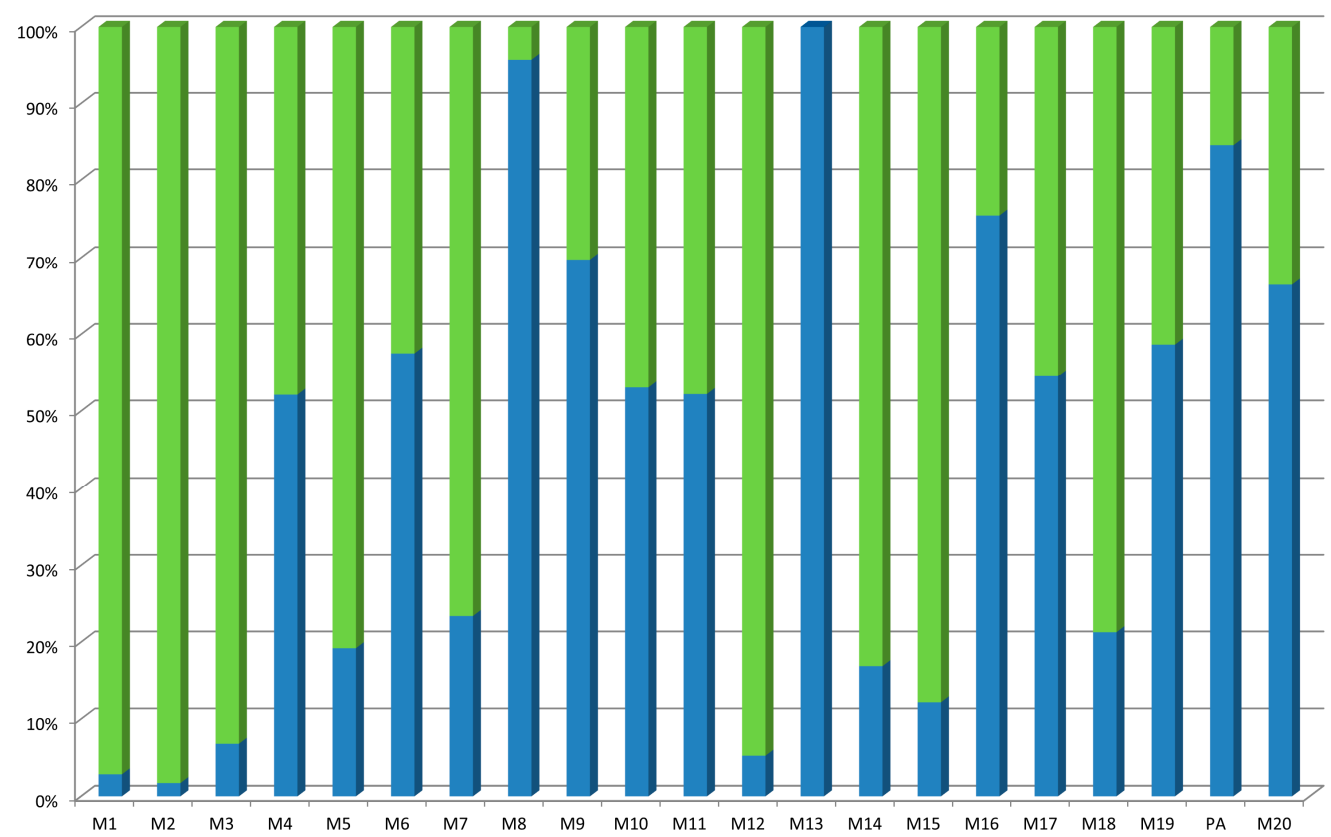

Figure 2. Comparative view of the relative intensity of GPS15290 metabolites in vitro in hepatocytes. Green: mouse metabolites, blue: rat metabolites. The starting pseudopeptide is GPS15290: pGua-[N 3 -hAla-MLR- $\beta$ hVal-RP-hPra]-W-OH (mass = 1352.7); M1 is (hPra -W)-(N $\mathrm{N}_{3}$-hAla-pGua) (mass = 604.2); M2 is R- $\beta$ hVal-RP (mass = 540.3); M3 is (hPra-W)-(N - -hAla-pGua)-M (mass = 735.3); M4 is $\beta$ hVal-RP-(hPra-W)-(N3-hAla-pGua) (mass = 970.5); M5 is P-hPra-(N $\mathrm{N}_{3}$-hAla -pGua)-MLR-

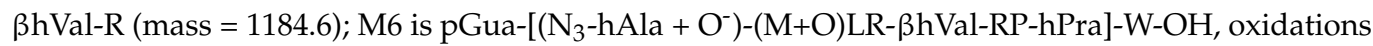
on Met and on $\mathrm{N}_{3}$-hAla (mass = 1384.7); M7 is R- $\beta$ hVal-RP-(hPra-W)-(( $\left.\mathrm{N}_{3}-\mathrm{hAla}+\mathrm{O}^{-}\right)$-pGua), oxidation on $\mathrm{N}_{3}$-hAla (mass = 1142.6); M8 is pGua-[N $\mathrm{N}_{3}$-hAla-MLR- $\beta$ hVal-RP-hPra] (mass is 1166.6); M9 is pGua-[N $\mathrm{N}_{3}$-hAla-(M+O)LR- $\beta$ hVal-RP-hPra]-W-OH oxidation on Met (mass = 1368.7); M10 is R$\beta$ hVal-RP-(hPra-W)-(N3-hAla-pGua) (mass = 1126.6); M11, with a mass of 1179.5 remained unknown; M12 is (hPra-W)-(N ${ }_{3}$-hAla-pGua)-ML (mass = 848.4); M13 is LR- $\beta$ hVal-RP-hPra-(N 3 -hAla-pGua) (mass = M1184.6); M14 is pGua-[N - hAla- $(\mathrm{M}+\mathrm{O})$ LR- $\beta$ hVal-RP-hPra]-W-OH, oxidation on Met and opening by hydrolysis (mass is 1386.7); M15 is pGua-[( $\left.\left.\mathrm{N}_{3}-\mathrm{hAla}+\mathrm{O}^{-}\right)-\mathrm{MLR}-\beta \mathrm{hVal}-\mathrm{RP}-\mathrm{hPra}\right]-\mathrm{W}-\mathrm{OH}$ oxidation on Met and opening by hydrolysis (mass = 1386.7); M16 is MLR- $\beta$ hVal-RP-(hPra-W)( $\mathrm{N}_{3}$-hAla-pGua) (mass is 1370.7); M17 is pGua-[( $\mathrm{N}_{3}$-hAla + $\left.\mathrm{O}^{-}\right)-\mathrm{MLR}-\beta$ hVal-RP-hPra]-(W + O)-OH, oxidations on Met and on Trp (mass is 1384.7); M18 is pGua-[N $\mathrm{N}_{3}-\mathrm{hAla}-\mathrm{MLR}-\beta$ hVal-RP-hPra]-W-OH, opening by hydrolysis (mass is 1370.7); M19 is pGua-[( $\left.\mathrm{N}_{3}-\mathrm{hAla}+\mathrm{O}^{-}\right)-\mathrm{MLR}-\beta$ hVal-RP-hPra]-W-OH, oxidation on $\mathrm{N}_{3}$-hAla (mass = 1368.7); M20 is pGua-[N $\mathrm{N}_{3}$-hAla-MLR- $\beta$ hVal-RP-hPra]-W-OH, opening by hydrolysis (mass is 1370.7). These attributions were carried out based on $\mathrm{ms} / \mathrm{ms}$ data. 

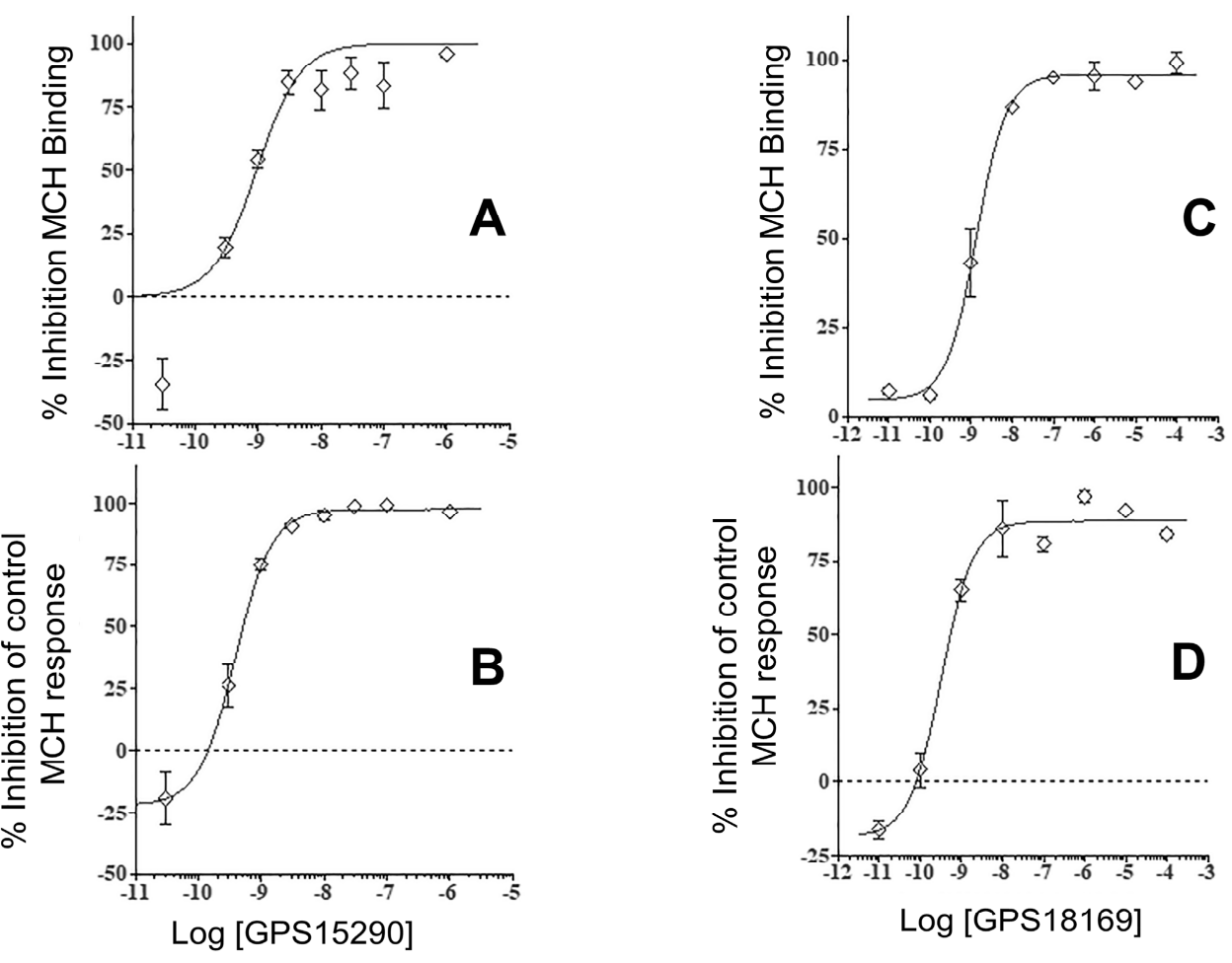

Figure 3. Examples of isotherms obtained with the two antagonistic pseudopeptides, GPS13290 and GPS18169. The assays were binding displacement experiments (panels A, B) of labelled MCH at membranes overexpressing the human $\mathrm{MCH}-\mathrm{R} 1$ or $\mathrm{MCH}$-induced cytosolic $\mathrm{Ca}^{2+}$ ion mobilization inhibition in living cells (panels C, D). The ligand was [ $\left.{ }^{125} \mathrm{I}\right]-\left[\mathrm{Phe}^{13}, \mathrm{Tyr}^{19}\right]-\mathrm{MCH}$. Independent experiments were performed at least twice using different batches of membranes from stably transfected $\mathrm{CHO}$ cells, and each point was obtained in triplicate. Concentration isotherms were obtained using eight concentrations of each product from 10-11 to 10-6 M. The data represent the mean $\pm \mathrm{SD}$ of the triplicate measure. Experiments were run at least twice, independently.

GPS18169 showed similar stability in plasma, as compared to GPS15290 (Table 5). We measured about $50 \%$ of the initial dose remaining after incubation in mice plasma in the case of GPS18169, while GPS15290 remained in the low 20\% range. With these data on GPS18169 at hand, the compound entered an in vivo experiment in the classical obesity model of high fat regimen.

\subsection{In Vivo Activity of GPS18169 in the Diet-Induced Obesity Model in Mice}

The model was classically established as detailed in the experimental section. In brief, four groups of mice were considered: a high-fat diet (HFD) (60\% of calories) fed group and a standard chow diet (STD) fed group from 4 weeks of age for 8 weeks before i.p. vehicle treatment for 12 weeks, and two groups of high-fat diet (HFD) fed and administered either 5 or $10 \mathrm{mg} / \mathrm{kg}$ of GPS18169 by daily intraperitoneal injections for 12 weeks. The treatments did not lead to any significant effect on serum uric acid (UA), creatinine, potassium $\left(\mathrm{K}^{+}\right)$ and sodium $\left(\mathrm{Na}^{+}\right)$levels when compared to the vehicle group on Week 16 (Day 113) and Week 20 (Day 141) (data not shown). On the contrary, variations were recorded considering the insulin, triglyceride levels and total cholesterol (see Table 6). A significant reduction in insulin was found after 12 weeks of treatment and, remarkably, the insulin level was back to the control, vehicle treated/normal diet when the mice were treated daily with $10 \mathrm{mg} / \mathrm{kg}$ of GPS18169 (grey cell, Table 6). Cholesterol and triglycerides levels remained high, despite a modest reduction during the treatments. 
Table 6. Blood biochemistry of diet-induced obese mice with and without treatment by the MCH-R1 antagonist GPS18169.

\begin{tabular}{|c|c|c|c|c|c|c|c|c|c|c|}
\hline & & \multicolumn{3}{|c|}{$\begin{array}{l}\text { Insulin } \\
\mathrm{pg} / \mathrm{mL}\end{array}$} & \multicolumn{3}{|c|}{$\begin{array}{c}\text { Total Cholesterol } \\
\text { mg/dL }\end{array}$} & \multicolumn{3}{|c|}{$\begin{array}{l}\text { Triglyceride } \\
\text { mg/dL }\end{array}$} \\
\hline & & Day 56 & Day 113 & Day 141 & Day 56 & Day 113 & Day 141 & Day 56 & Day 113 & Day 141 \\
\hline \multirow{2}{*}{$\begin{array}{c}\text { Vehicle } \\
\text { (Normal Diet) }\end{array}$} & Mean & 381.1 & 438.3 & 760.7 & 98.1 & 103.1 & 101.2 & 69.5 & 86.3 & 78.3 \\
\hline & SEM & 51.7 & 57.2 & 79.7 & 2.4 & 2.8 & 4.5 & 4.8 & 5.3 & 6.4 \\
\hline \multirow{2}{*}{$\begin{array}{c}\text { Vehicle } \\
\text { (High-Fat Diet) }\end{array}$} & Mean & 887.0 & $2543.0+$ & $2016.6+$ & $155.6+$ & $163.6+$ & $157.7+$ & $123.4+$ & $122.1+$ & $123.5+$ \\
\hline & SEM & 126.9 & 383.3 & 477.2 & 8.9 & 8.9 & 17.5 & 6.7 & 5.7 & 11.6 \\
\hline \multirow{2}{*}{$\begin{array}{c}\text { GPS18169 } \\
\text { (High-Fat Diet) }\end{array}$} & Mean & 1068.0 & 1549.7 & 957.0 * & 155.6 & 135.7 & 132.1 & 122.9 & 108.3 & 102.1 \\
\hline & SEM & 145.9 & 370.8 & 371.8 & 7.4 & 9.3 & 6.6 & 3.5 & 6.0 & 3.3 \\
\hline \multirow{2}{*}{$\begin{array}{c}\text { GPS18169 } \\
\text { (High-Fat Diet) }\end{array}$} & Mean & 909.5 & 1983.8 & 760.4 * & 158.3 & 143.1 & 135.6 & 121.8 & 115.3 & 108.9 \\
\hline & SEM & 125.6 & 554.7 & 201.4 & 7.0 & 13.9 & 14.6 & 4.6 & 6.0 & 9.4 \\
\hline
\end{tabular}

$\left.{ }^{*}\right) 10 \mathrm{mg} / \mathrm{kg}$ daily (QD) x 12 weeks; ${ }^{* *} 5 \mathrm{mg} / \mathrm{kg}$ QD x 12 weeks; Two-way ANOVA followed by Bonferroni test was applied for comparison between the vehicle and treated groups at each time point. Differences are considered significant at ${ }^{\dagger} p<0.05$, vs. Vehicle (Normal Diet); ${ }^{*} p<0.05$, vs. Vehicle (High-fat Diet) (see red cells). Complete individual data can be found in Table S2 (Blood chemistry). SEM is standard error of the mean.

Compared to the vehicle control group, intraperitoneal injection of GPS18169 at 5 and $10 \mathrm{mg} / \mathrm{kg}$ once daily for 12 weeks was not associated with any significant effect on serum aspartate aminotransferase (AST) and alanine aminotransferase (ALT) levels on day 113 and day 141 .

The weight of the five adipose tissues, including epididymal, mesenteric, retroperitoneal, inguinal, and brown fat, from C57BL/ 6 mice fed a high-fat diet was significantly $(p<0.05)$ increased compared to the mice fed a standard chow diet (STD). Intraperitoneal injection (IP) of GPS18169 at 5 and $10 \mathrm{mg} / \mathrm{kg}$ once daily for 12 weeks showed a significant $(p<0.05)$ decrease in the weight of mesenteric, retroperitoneal, inguinal, and brown fat on Week 20 (Day 141). The weight ratio of adipose tissue to the whole body (g/100 g of body weight $[\mathrm{BW}]$ ) was constant in the study (Table 7).

The food and water intake in the group of C57BL/6 mice fed a high-fat diet was significantly $(p<0.05)$ decreased during the study period when compared to the group of mice fed a standard chow diet (STD). However, the food and water intake between the vehicle and test article treated groups was similar during the study period (Tables S4 and S5 and Figure 4 A,B).

Moreover, body weight gain in the group of C57BL/6 mice fed a high-fat diet during the study period between Week 4 (Day 29) and Week 20 (Day 141) was significantly $(p<0.05)$ higher than that in the group of mice fed a standard chow diet (STD) (Figure 5). Intraperitoneal injection (IP) of GPS18169 at 5 and $10 \mathrm{mg} / \mathrm{kg}$ once daily for 12 weeks showed a significant $(p<0.05)$ decrease in body weight gain from Day 117 to Day 141 when compared to the vehicle group that were similarly injected once daily with the vehicle (Figure 5). Neither overt toxicities nor behavioral modifications were observed in the treated animals in the study, while some behavioral concerns have been reported with other MCH-R1 antagonist treatments, such as for TASP0382650 [39], ATC0065 [40] GW803430 [41] or SNAP-7941 [42] (among others, see [43,44]). 
Table 7. Comparison of the adipose tissue weights between lean, high fat diet fed and GPS18169-treated mice.

\begin{tabular}{|c|c|c|c|c|c|c|c|c|c|c|c|c|c|}
\hline \multirow[t]{3}{*}{ Treatment } & \multirow[t]{3}{*}{ Dose } & & \multirow{2}{*}{$\begin{array}{c}\text { BW (g) } \\
\text { Day } 141\end{array}$} & \multicolumn{8}{|c|}{ Adipose Tissue Weight (g) } & & \\
\hline & & & & \multicolumn{2}{|c|}{ Epididymal } & \multicolumn{2}{|c|}{ Mesenteric } & \multicolumn{2}{|c|}{ Retroperitoneal } & \multicolumn{2}{|c|}{ Inguinal } & \multicolumn{2}{|c|}{ Brown Fat } \\
\hline & & & $\mathrm{g}$ & $\mathrm{g}$ & $\% \mathrm{BW}$ & $\mathrm{g}$ & $\% \mathrm{BW}$ & g & $\% \mathrm{BW}$ & g & $\% \mathrm{BW}$ & g & $\% \mathrm{BW}$ \\
\hline \multirow{2}{*}{$\begin{array}{c}\text { Vehicle } \\
\text { (Normal Diet) }\end{array}$} & \multirow{2}{*}{$\begin{array}{c}10 \mathrm{~mL} / \mathrm{kg} \text { QD } \\
\text { x } 12 \mathrm{wks}\end{array}$} & Mean & 27.2 & 0.735 & 2.66 & 0.345 & 1.26 & 0.219 & 0.79 & 0.402 & 1.46 & 0.099 & 0.36 \\
\hline & & SEM & 0.5 & 0.063 & 0.20 & 0.021 & 0.06 & 0.025 & 0.08 & 0.034 & 0.11 & 0.006 & 0.02 \\
\hline \multirow[t]{2}{*}{$\begin{array}{c}\text { Vehicle } \\
\text { (High-fat Diet) }\end{array}$} & \multirow[t]{2}{*}{$\begin{array}{c}10 \mathrm{~mL} / \mathrm{kg} \text { QD } \\
\text { x } 12 \mathrm{wks}\end{array}$} & Mean & $40.0+$ & $1.972+$ & $4.98+$ & $0.688+$ & 1.68 & $0.779+$ & $1.87+$ & $1.725+$ & $4.16+$ & $0.164+$ & 0.40 \\
\hline & & SEM & 2.6 & 0.152 & 0.30 & 0.082 & 0.11 & 0.116 & 0.17 & 0.222 & 0.33 & 0.018 & 0.02 \\
\hline \multirow[t]{2}{*}{ GPS18169-002 } & \multirow{2}{*}{$\begin{array}{c}10 \mathrm{mg} / \mathrm{kg} \text { QD } \\
\text { x } 12 \mathrm{wks}\end{array}$} & Mean & $29.9 *$ & 1.991 & 6.71 & $0.334 *$ & $1.08 *$ & 0.320 * & $1.01 *$ & $0.892 *$ & 2.77 & $0.084^{*}$ & 0.27 * \\
\hline & & SEM & 1.4 & 0.141 & 0.47 & 0.047 & 0.11 & 0.064 & 0.17 & 0.206 & 0.55 & 0.009 & 0.02 \\
\hline \multirow[t]{2}{*}{ GPS18169-002 } & \multirow[t]{2}{*}{$\begin{array}{c}5 \mathrm{mg} / \mathrm{kg} \text { QD x } \\
12 \mathrm{wks}\end{array}$} & Mean & $29.8^{*}$ & 1,882 & 6.67 & $0.351 *$ & 1.08 * & 0.321 * & $0.97 *$ & $0.922 *$ & 2.69 & $0.096^{*}$ & 0.30 * \\
\hline & & SEM & 2.4 & 0.148 & 0.66 & 0.094 & 0.19 & 0.093 & 0.21 & 0.314 & 0.73 & 0.023 & 0.04 \\
\hline
\end{tabular}

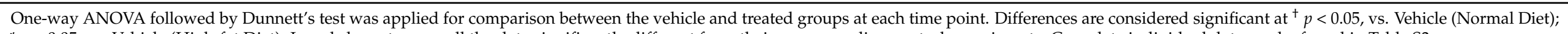

${ }^{*} p<0.05$, vs. Vehicle (High-fat Diet). In red characters are all the data significantly different from their corresponding control experiments. Complete individual data can be found in Table S3. 


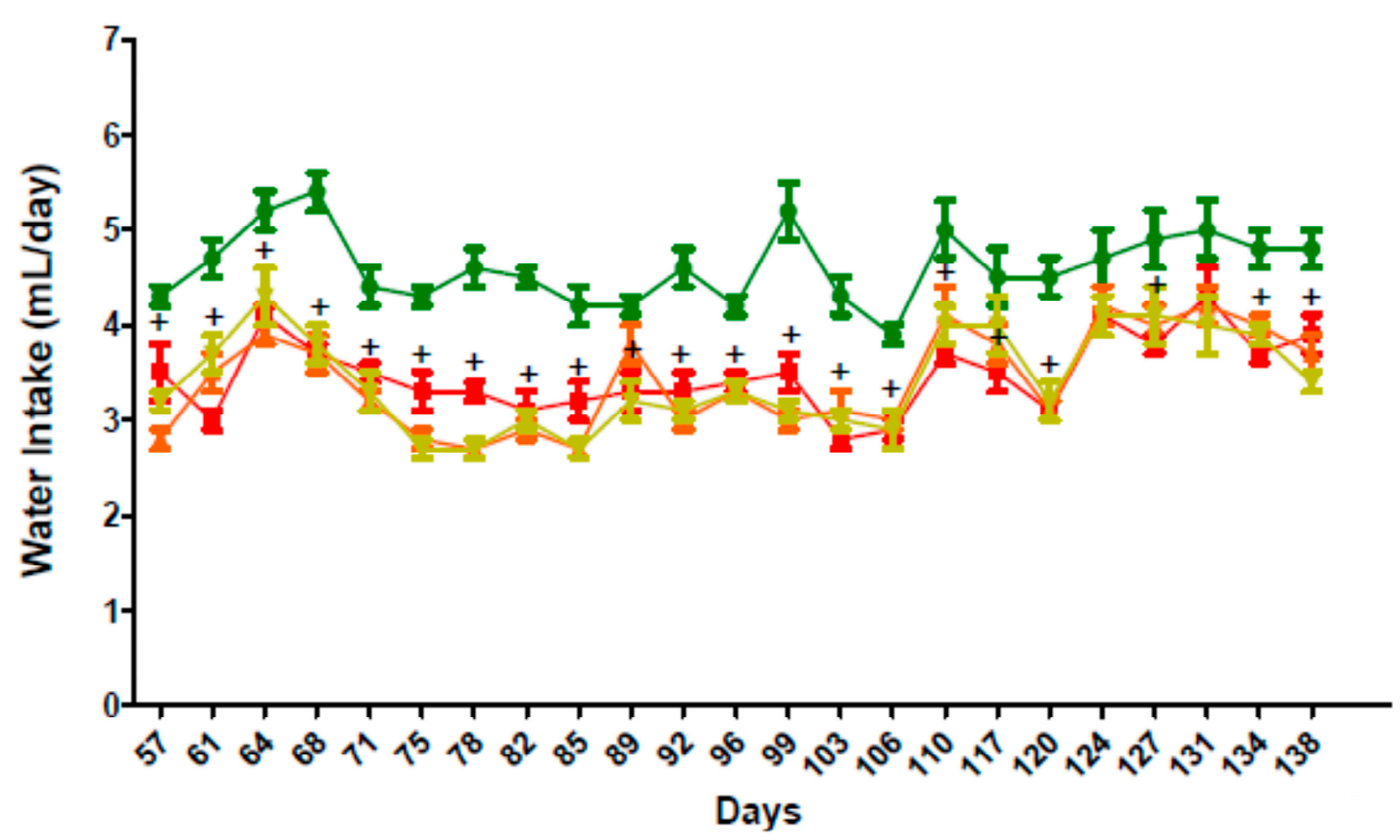

A

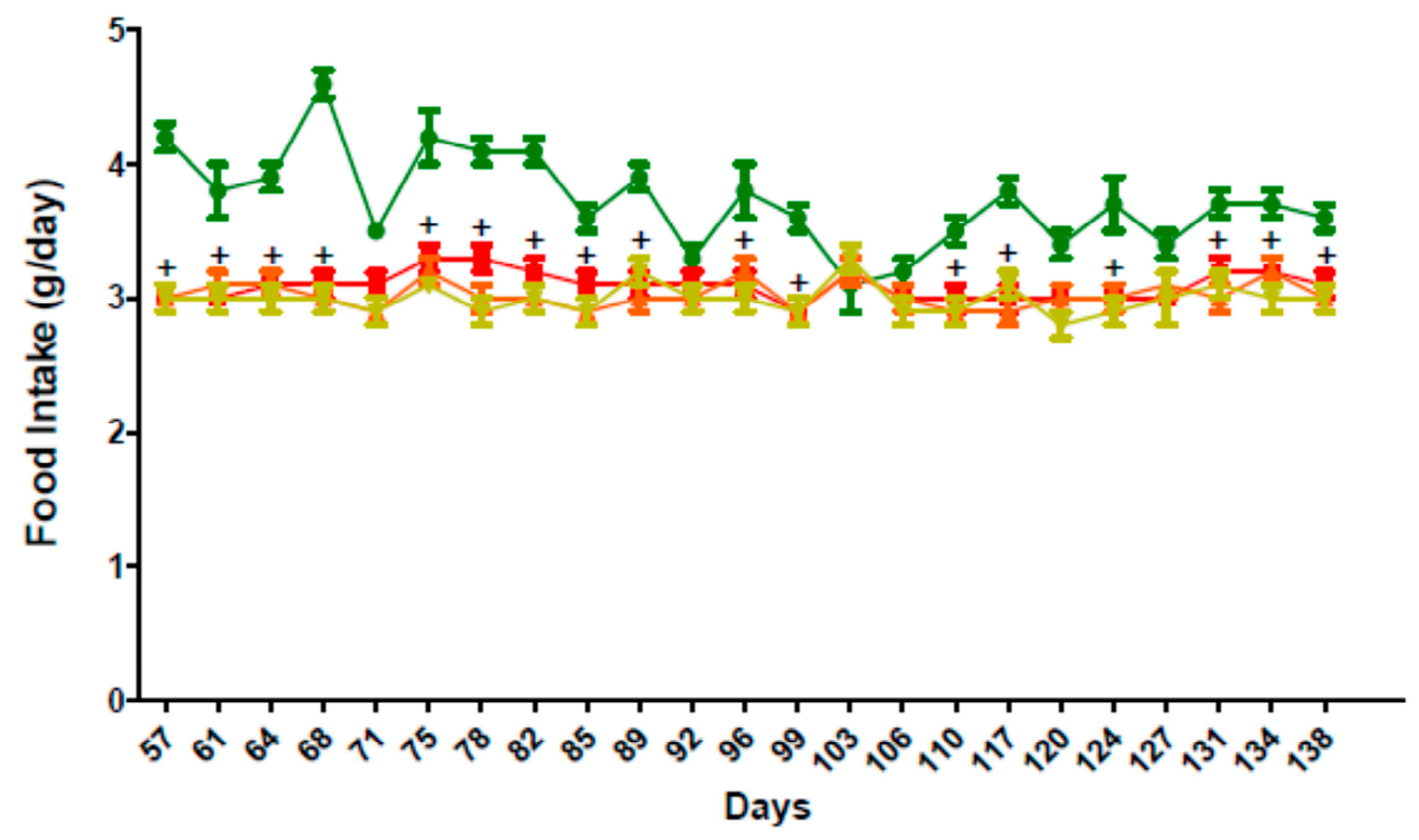

B

Figure 4. Water (A) and food (B) intake in high-fat diet-induced obesity model in C57BL/6 mice. Male C57BL/6 mice were fed a high-fat diet (HFD, 60\% of calories) or a standard chow diet (STD) from 4 weeks of age for 8 weeks before treatment. Once obesity was installed, GPS18169, at 5 and $10 \mathrm{mg} / \mathrm{kg}$ and vehicle (WFI) was administered by intraperitoneal injection (IP) once daily for 12 weeks after 8 weeks of HFD feeding. Food (B) and water (A) intake were recorded twice weekly. ${ }^{+} p<0.05$, vs. Vehicle (High-fat Diet); two-way ANOVA followed by Bonferroni test. Green squares: vehicle and normal diet; red squares: vehicle and high fat diet; orange triangles: GPS18169 $(10 \mathrm{mg} / \mathrm{kg})$ and high fat diet; greenish-yellow triangles: GPS18169 (5mg/kg) and high fat diet. Complete individual data are presented in Table S4 (Water) and Table S5 (Food). 


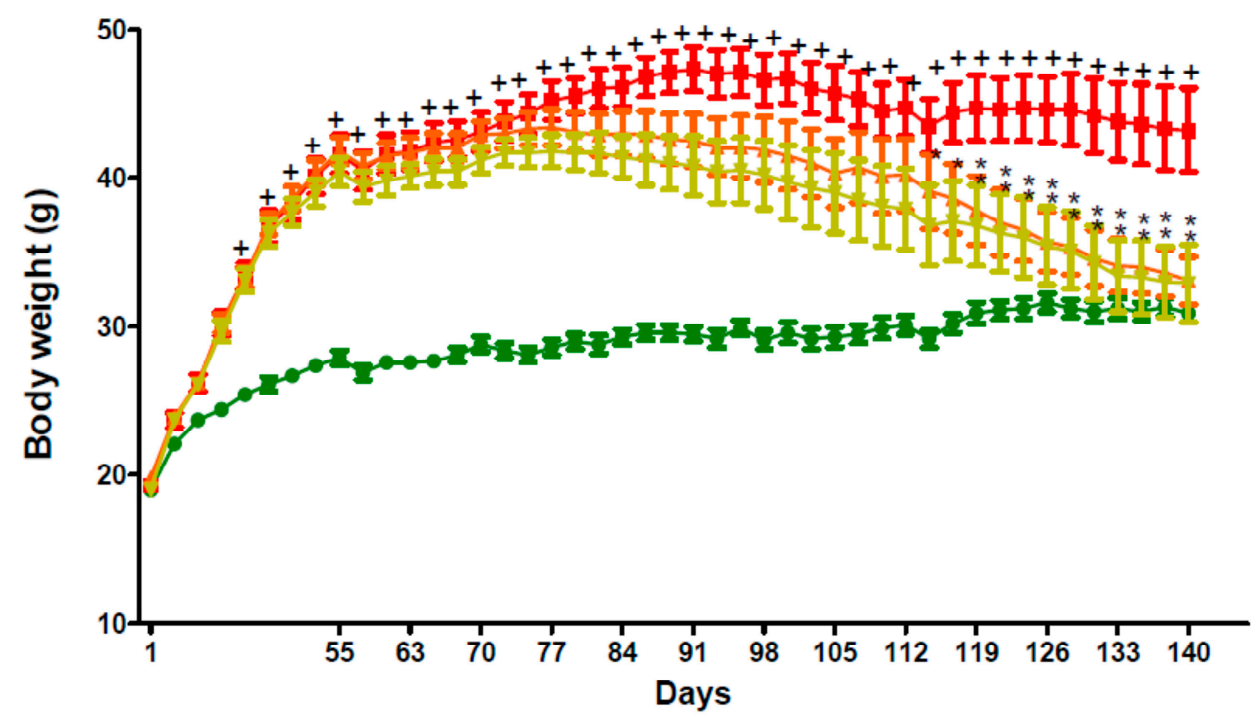

Figure 5. Body weight changes in high-fat diet-induced obesity model in C57Bl/6 mice. Male C57BL/ 6 mice were fed a high-fat diet (HFD) (60\% of calories) or a standard chow diet (STD) from 4 weeks of age for 8 weeks before treatment. Test article, GPS18169, at 5 and $10 \mathrm{mg} / \mathrm{kg}$ and vehicle (WFI) were administered by intraperitoneal injection (IP) once daily for 12 weeks after 8 weeks of HFD feeding. The body weight was measured thrice a week. Complete individual data are presented in Table S6 (body weight changes).

\section{Discussion}

Obesity, and subsequent complications including, but not limited to, diabetes, is a world-scale problem, enhancing the death rate and the cost of maintaining the population in good health. Because of this, since the late 1980s, it was declared a priority to find ways to fight obesity. In general, two types of obesity could be distinguished: (i) the genetic one [45], such as leptin deficiency [46], in which mutations can lead to the over-accumulation of fat or, in some cases, linked to pharmacological treatments such as anti-HIV therapies [47], and (ii) the obesity linked to the lack of control of appetite, as well as universal access to food regimens over-rich in both fat and sugar (commonly called cafeteria regimens [48] or Western diet [49]).

Although the goal of the present work was not to discuss the structural aspects of the molecular pause of the antagonist(s) onto the receptor, some observations are worth mentioning, without going into more technological approaches such as molecular modeling. Originally, the natural agonist, $\mathrm{MCH}$, was engineered to bring in several unnatural features to introduce higher stability and patentability, and to obtain antagonist(s). At first, we identified a minimal binding sequence from $\mathrm{MCH}$. It resulted in the peptide from which five $\mathrm{N}$-terminal amino-acids [Asp-Phe-Asp-Met-Leu] and two of the C-terminal side [Gln-Val] were deleted [26]. The final product was a shorter agonist with an affinity at the MCH-R1 receptor superior to the natural peptide [26]. To reach that goal, we produced more than 200 analogues with, early on, the change of the N-terminal amino acid, arginine, by a p-guanidino benzoic acid. In doing so, the $\mathrm{N}$-terminal amino group was removed, and with it, the possibility for the peptide to be catabolized by exo-aminopeptidase. On the contrary, the C-terminal amino-acid, tryptophan, could not be substituted so radically, and only close analogues, such as 3-benzothienylalanine, were introduced. We turned the agonist into an antagonist by deleting the Gly in position 10 of the natural hormone [28], leading to S38151. This compound served as a starting point for the present investigation with the goal to replace the S-S bridge, synonymous of poor stability in vivo, with a more stable version of the antagonist. Interestingly, our initial attempts to produce the cyclic part of the peptide S38151 (including a cystine bridge) led to completely inactive molecules [26]. We realized rapidly that the tyrosine (at position 13 of the original hormone) was not necessary 
to sustain the activity of the corresponding peptide, a feature that escaped our attention in our previous explorations $[26,28]$. Our main surprise was the observation that, despite the slight hindrance of the triazole moiety (when compared to the disulfide bridge) introduced in the bridge of the pseudopeptide, the best peptide belongs to this click-generated family of compounds. Because we tried to substitute the S-S bridge, we wrongly reasoned that a rather flat moiety deprived of chemical cycles would create a better balance between stability and affinity/activity. GPS18169, on the contrary, bears a penta-atom cycle in the bridge. Furthermore, the combination of the size of the cycle and the different amino acids at different positions in the sequence was obvious. For example, inside the lactam family of analogues sharing the same cycle size resulting from the incorporation of the same acid/base side chains (Table 4), several "mutations" led to compounds with Ki below $1 \mathrm{nM}$, although the differences at this level of activity/affinity should be taken cautiously. Similarly, certain compounds coming from the triazole family showed that the affinity of the initial compound could be "ameliorated", for example, GPS15363. To maintain a 29-atom ring as in the initial antagonist S38151, we had to compensate for the triazole bridge that would count for seven atoms. The suppression of $\mathrm{Tyr}^{8}$ in the sequence made for a three heavy atom compensation, and the last ones were compensated as follows: at the position "7", a beta-amino acid, beta-homovaline, was incorporated instead of the original Val. It is interesting to note that the size of the triazole should account for more than three atoms, as a supplementary compensation was necessary to recover the potent activity of the initial compound.

Initially, we started by testing GPS18169 in a genetic model of obesity (fa/fa rats) related to a defect in the leptin receptor. The experiments failed as no changes were recorded between treated and untreated animals (data not shown), unsurprisingly suggesting that leptin-independent pathway(s) exist(s) in the pathophysiology of genetic obesity that does not involve the MCH pathway. A leptin-independent animal model should be used to confirm the implication of the $\mathrm{MCH}$ pathway and the effect of receptor antagonist(s) in regulating food intake and weight control. To document the properties of these antagonistic putative peptides derived from $\mathrm{MCH}$, we used the established diet-induced obesity model $[50,51]$, as it reflects the situation of the overweight/obesity pandemic represented in most Western countries [52], and beyond [53]. Peptides such as D-Ala2Met-enkephalinamide [54] or NPY5 [55] and MCH were among the targets explored in the past to attempt to control appetite. The MCH-R1 antagonists might very well fill the task, as they seem to act not only at the central level [42] but also peripherally [56], maybe by enhancing the energetical use of fat.

On the physio-pathological side, although without digging into the details of the possible mechanism(s) of action of the antagonist downstream its receptor, one should point out several points. First, due to the affinity of the GPS18169 at its receptor, in the low nanomolar range, and its pseudopeptidic nature, one could be convinced that the compound is rather specific to its target, a feature always difficult to prove and obtain with small molecules. Second, the cyclisation by click chemistry could be an avenue to stabilize naturally occurring cyclic peptides with an original S-S bridge, and cyclic peptide examples are numerous (see, for example, Bockus et al. [57]). Incidentally, these authors stressed that "naturally occurring cyclic peptides exhibit a wide variety of unusual and potent biological activities" and "penetrate cells by passive diffusion", which significantly point to the necessity to exploit more from natural sources, even peptides, the structure of which might seem complex at first glance (see also discussion in Boutin et al. [35]). Third, the decrease observed in adipose tissue mass in the treated animals also concurs with the widely admitted fact that adipose tissue has a role as an endocrine regulator of insulin resistance [58,59]. It is concluded that GPS18169, given at 5 and $10 \mathrm{mg} / \mathrm{kg}$ intraperitoneally once daily for 12 weeks, had significant protective effects in the study, and this effect was accompanied by an improvement in body weight gain and serum insulin, total cholesterol (TC) and triglyceride (TG) levels. The GPS18169 treatment also showed a significant decrease in adipose tissue weight in a high-fat diet-induced obesity model in C57BL/6 mice. 
This program started more than 20 years ago [26]. The final stages were designed to answer three questions: Would it be possible to extrapolate from our acquired knowledge on MCH antagonists [26,28] peptide or pseudopeptidic structures that would be stabilized, as compared to our previous candidate, S38151? Would they be as potent as the previous peptides in our molecular pharmacology assay? Would the best candidate be active in one in vivo assay? Using this new compound, we clearly answered the three questions: natural cyclic peptides could be stabilized using alternative bridge approaches, without changing their affinity at the receptor. These observations and consequent syntheses of pseudopeptides led to a compound with interesting anti-obesity (or anti-obesity-leading complications, such as insulin decrease) features. If the latter observation is limited to the $\mathrm{MCH}$ system and obesity, the two former answers have a more general exemplification role, such as how to manipulate peptide chemistry to obtain accurate tools (or drugs?).

\section{Materials and Methods}

\subsection{General Information}

Standard Fmoc-amino acids, Oxyma Pure, $N, N^{\prime}$-diisopropylcarbodiimide (DIC), FmocL-hArg(Pbf)-OH (CAS No: 1159680-21-3), Fmoc-D-Arg(Pbf)-OH (CAS N : $^{\circ}$ 187618-60-6), Fmoc-5-Ava-OH (CAS No: 123622-48-0), Fmoc-L-2-Abu-OH (CAS No: 135112-27-5), FmocL-Asp(OAll)-OH (CAS N: 146982-24-3), Fmoc-L-Dap(Alloc)-OH (CAS Nº: 188970-92-5), Fmoc-L-Glu(OAll)-OH (CAS N: 133464-46-7), Fmoc-L-Orn(Alloc)-OH (CAS N: 14729011-7), Fmoc-L-N-Me-Cys(Trt)-OH (CAS Nº 944797-51-7), Fmoc-L-beta-hMet-OH (CAS $\mathrm{N}^{\circ}$ : 266359-48-2), Fmoc-L-ethionine (CAS No: 1562431-51-9), Fmoc-L-buthionine (CAS $\mathrm{N}^{\circ}$ : 1821797-31-2), Fmoc-L-Selenomethionine (CAS N: 1217852-49-7), Fmoc-L-Pra-OH (CAS N: 198561-07-8), Fmoc-L-Aha-OH (CAS Nº 942518-20-9), Fmoc-L-Nle-OH (CAS N: 77284-32-3), Fmoc-L-Tle-OH (CAS Nº: 132684-60-7), Fmoc- Aib-OH (CAS Nº: 94744-50-0), Fmoc-L-Arg(NO2)-OH (CAS N: 58111-94-7), Fmoc-L-Arg(Me,Pbf)-OH (CAS N: 113561649-7), Fmoc-L-Cit-OH (CAS N: 133174-15-9), Fmoc-L-Cav(Boc)-OH (CAS N: 190723-97-8), Fmoc-L-Pro(4-NHBoc)-OH (CAS N ${ }^{\circ}$ 221352-74-5), Fmoc-L-5,5-di-Me-Pro-OH (CAS N ${ }^{\circ}$ : 1310680-23-9), Fmoc-L-Pro(4-CF3)-OH (CAS No: 1242934-32-2), Fmoc-L-Pro(4-Ph)-OH (CAS N: 269078-71-9), Fmoc-4-Abz-OH (CAS N: 185116-43-2), Fmoc-L-Lys(N3)-OH (CAS N: 159610-89-6), Fmoc-L-beta-hVal-OH (CAS N: 172695-33-9) and WANG resin (200-400 mesh, $0.34 \mathrm{mmol} / \mathrm{g}$ ) were purchased from Iris Biotech. Fmoc-5,5,5-trifluoroDL-Leu-OH (CAS N: 777946-04-0), Fmoc-4,5-dehydro-L-Leu-OH (CAS N: 87720-55-6), Fmoc-4-hydroxy-L-Leu-OH, and Fmoc-Bta-OH (CAS N: 177966-60-8) were purchased from Eurogentec. Fmoc-L-Hpra-OH (CAS Nº : 942518-21-0), Fmoc-N-Me-L-Met-OH (CAS $\mathrm{N}^{\circ}:$ 84000-12-4), and Fmoc-N-Me-L-Trp-OH (CAS No: 112913-63-0) were purchased from ChemPep. Dimethylformamide (DMF), $\mathrm{CH}_{2} \mathrm{CL}_{2}$, methanol, diethyl ether, and HPLC-grade acetonitrile were purchased from Sigma-Aldrich, St Louis, Mo, USA.

\subsection{Peptide Synthesis}

All peptides were synthesized at 100 mole scale using Fmoc-SPPS on a SymphonyX instrument (Gyros Protein Technologies, Uppsalan Sweden). The standard deprotectioncoupling cycle for each residue consisted of six steps: 1 . Wash with $5 \mathrm{~mL}$ of DMF $(3 \times 30 \mathrm{sec})$; 2 . Fmoc group deprotection with $5 \mathrm{~mL}$ of $20 \%$ piperidine in DMF $(3 \times 3 \mathrm{~min})$; 3. Wash with $5 \mathrm{~mL}$ of DMF $(3 \times 30 \mathrm{sec}) ; 4$. Fmoc-AA-OH coupling $(2 \times 60 \mathrm{~min}) ; 4 \mathrm{a} .5 \mathrm{~mL}$ of $0.2 \mathrm{M}$ Fmoc-AA-OH in DMF; $4 \mathrm{~b} .2 \mathrm{~mL}$ of $0.5 \mathrm{M}$ OxymaPure in DMF; 4c. $1 \mathrm{~mL}$ of $1 \mathrm{M}$ DIC in DMF; 5. Capping with $5 \mathrm{~mL}$ of $10 \% \mathrm{Ac} 2 \mathrm{O}$ in DMF (7 min); and finally 6. Wash with $5 \mathrm{~mL}$ of $\mathrm{DMF}(3 \times 30 \mathrm{sec})$.

Upon completion of the synthesis, peptide resins were washed $3 \times$ with DMF and $3 \times$ with $\mathrm{CH}_{2} \mathrm{CL}_{2}$. Peptides were then cleaved with one of three trifulroacetic acid (TFA) cleavage cocktails (per $100 \mu$ mole scale synthesis): (a) Cocktail \#1: Peptides containing neither Met nor Cys: $18 \mathrm{~mL}$ TFA, $500 \mu \mathrm{L}$ triisopropylsilane (TIS), $500 \mathrm{mg}$ phenol, $1000 \mu \mathrm{L}$ water; (b) Cocktail \#2: Peptides containing Cys, but no Met: $17.5 \mathrm{~mL}$ TFA, $500 \mu \mathrm{L}$ TIS, $500 \mathrm{mg}$ phenol, $1000 \mu \mathrm{L}$ water, $500 \mu \mathrm{L}$ EDT; or (c) Cocktail \#3: Peptides containing Met: 
$17.5 \mathrm{~mL}$ TFA, $500 \mu \mathrm{L}$ TIS, $500 \mathrm{mg}$ phenol, $1000 \mu \mathrm{L}$ water, $500 \mu \mathrm{L}$ EDT and $500 \mu \mathrm{L}$ tetrabutylammonium bromide. After $3 \mathrm{~h}$ of TFA cleavage, the cleavage solution was filtered from the resin, and peptides were precipitated by addition to $40 \mathrm{~mL}$ of ice-cold diethyl ether. After $>1 \mathrm{~h}$ at $-20^{\circ} \mathrm{C}$, ether solutions were centrifuged at $3500 \mathrm{rpm}$, and the supernatants were decanted. Pellets were washed twice with diethyl ether and then dried for $>3 \mathrm{~h}$ in a vacuum desiccator before dissolution, analytical characterization, and purification. The peptides were analyzed by Ultra Performance Liquid Chromatography (UPLC) and Electrospray Ionization Mass Spectrometry (ESI-MS). The instruments were equipped with BEH C18 (Waters), $150 \mathrm{~mm} \times 2.1 \mathrm{~mm}$ (flow rate: $0.6 \mathrm{~mL} / \mathrm{min}$ ). Solvents A and B were $0.1 \%$ TFA in water and $0.1 \%$ TFA in acetonitrile. One hundred and three peptides were synthesized in this project.

\subsubsection{Synthesis of Peptides with Lactam Bridge}

Peptides were prepared by standard Fmoc-SPPS as described above, using protected amino acids. Upon completion of the linear peptide synthesis, the Alloc group was removed. $\mathrm{PhSiH} 3$ (25 eq.) in $5 \mathrm{~mL}$ of $\mathrm{CH}_{2} \mathrm{Cl}_{2}$ was added to the resin followed by $\mathrm{Pd}(\mathrm{PPh} 3) 4$ (0.25 eq.) in $\mathrm{CH}_{2} \mathrm{Cl}_{2}$. After $1 \mathrm{~h}$ resin agitating in the dark, the solution was drained and the reaction was repeated. The resin was washed with 3 volumes of $\mathrm{CH}_{2} \mathrm{Cl}_{2}, 4$ volumes of $1 \mathrm{M}$ pyridine in DMF and 3 volumes of DMF. OxymaPure (3 eq.) and DIC (3 eq.) in $5 \mathrm{~mL}$ of DMF were added to the resin and agitated overnight. The resin was washed with 3 volumes of DMF and 3 volumes of $\mathrm{CH}_{2} \mathrm{Cl}_{2}$. After standard peptide cleavage conditions (described above), the crude peptide was purified by Preparative HPLC and lyophilized.

\subsubsection{Synthesis of Peptides with a Disulfide Bridge}

Peptides were prepared by standard Fmoc-SPPS as described above, using protected amino acids. After standard peptide cleavage conditions (described above), the crude peptide was dissolved in $200 \mathrm{~mL}$ of acetic acid solution $\left(\mathrm{AcOH} / \mathrm{H}_{2} \mathrm{O}\right.$ 1:9), then a solution of $0.06 \mathrm{M}$ iodine in $\mathrm{MeOH}$ was added dropwise with rapid stirring until the solution became slightly yellow. The excess of iodine was quenched with $1 \mathrm{M}$ ascorbic acid and the crude peptide was purified by Preparative HPLC and lyophilized.

\subsubsection{Synthesis of Peptides with Triazole Bridge on a Solid Support}

Peptides were prepared by standard Fmoc-SPPS as described above, using protected amino acids. Upon completion of the linear peptide synthesis on a solid support, $\mathrm{CuI}$ ( 2 eq.), sodium ascorbate (2 eq.) and $N, N$-diisopropylethylamine (DIPEA) (3 eq.) in $5 \mathrm{~mL}$ of $\mathrm{N}$-methyl pyrrolidone were added to the resin. After $1 \mathrm{~h}$ agitation of the resin under an inert atmosphere, the solution was drained and the resin was washed consecutively with $0.5 \%$ DIPEA in DMF, $0.5 \%(w / w)$ sodium diethyldithiocarbamate in DMF and $1 \mathrm{M}$ pyridine in DMF and DMF to remove the catalyst. After standard peptide cleavage conditions (described above), the crude peptide was purified by preparative HPLC and lyophilized.

\subsection{Purification and Analyses}

Purifications of crude peptides were performed with a preparative reversed phase HPLC (Waters Delta Prep 4000, Waters Corp, Milford, MA, USA) system using a reversed phase column (Vydac Denali prep C-18, $10 \mu \mathrm{m}, 120 \AA, 50 \times 300 \mathrm{~mm}$ ) (VWR, Radnor, PA, USA) and an appropriate gradient of increasing concentration of buffer B in buffer A (flow rate of $80 \mathrm{~mL} / \mathrm{min}$ ). The fractions containing the purified target peptide were identified by UV measurement (Waters $2489 \mathrm{UV} /$ Visible detector) at $214 \mathrm{~nm}$ and selected fractions were then combined and lyophilized.

A summary of the peptide sequences is presented in Table S1, while their analytical characteristics are shown in Supplementary Table S1. Peptides were numbered according to Genepep internal system (GenePep Synthesis). 


\subsection{Establishment of a Stable Cell Line Expressing Human MCH Receptor}

Stable cell lines were obligatory for all receptor programs. We cloned the human receptor and established the cell line as previously described [26,27]. In brief, HEK293 (HEK) cells were grown in Dulbecco's Modified Eagle medium (DMEM) supplemented with $10 \%$ fetal calf serum, $2 \mathrm{mM}$ glutamine, $100 \mathrm{IU} / \mathrm{mL}$ penicillin and $100 \mathrm{mg} / \mathrm{mL}$ streptomycin. They were seeded at $5 \times 10^{6}$ cells in $T 75 \mathrm{~cm}^{2}$ culture flasks. One day later, they were transfected with $10 \mathrm{mg}$ of the pcDNA3.1 (Invitrogen, Groningen, The Netherlands) containing the human MCH-R1 using lipofectamine (Life Technologies, Cergy Pontoise, France), as previously described. One day later, cells were trypsinized, resuspended in a complete DMEM medium containing $800 \mathrm{mg} / \mathrm{mL}$ of geneticin and seeded at different dilutions in 96-well plates which were kept for 2 to 3 weeks in a humidified $\mathrm{CO}_{2}$ incubator. At the end of the selection period, isolated clones were picked up, amplified, and further characterized by cyclic AMP experiments. For each cell line, one positive clone was subcloned before being used for all of the cyclic AMP, $\left[{ }^{35} \mathrm{~S}\right]-\mathrm{GTP} \gamma \mathrm{S}$ and receptor binding experiments necessary to characterize them [26]. The stable HEK293 cell line expressing the human MCH-R1 was HEK-hMCH-R1.

\subsection{Membrane Preparation and Binding}

Membrane preparations were classically made as previously described [26,27]. In brief, the HEK-hMCH-R cell line was grown to confluency, harvested in PBS buffer containing 2 $\mathrm{mM}$ EDTA and centrifuged at $10,000 \times g$ for $5 \mathrm{~min}\left(4^{\circ} \mathrm{C}\right)$. The resulting pellet was suspended in $20 \mathrm{mM}$ Hepes buffer ( $\mathrm{pH} 7.5$ ), containing $5 \mathrm{mM}$ EGTA and homogenized using a Kinematica polytron. The homogenate was then centrifuged $\left(95,000 \times \mathrm{g}, 30 \mathrm{~min}, 4{ }^{\circ} \mathrm{C}\right)$ and the resulting pellet was suspended in $50 \mathrm{mM}$ HEPES buffer ( $\mathrm{pH} 7.5$ ), containing 10 $\mathrm{mM} \mathrm{MgCl} 2$ and $2 \mathrm{mM}$ EGTA. Aliquots of membrane preparations were stored at $-80^{\circ} \mathrm{C}$ until use. Binding has been described in numerous publications and the test was based on Mac Donald et al.'s description [60]. Cell membrane homogenates (4 $\mu \mathrm{g}$ protein) are incubated for $60 \mathrm{~min}$ at $22{ }^{\circ} \mathrm{C}$ with $\left.0.1 \mathrm{nM} \mathrm{[}{ }^{125} \mathrm{I}\right]-\left[\mathrm{Phe}^{13}, \mathrm{Tyr}^{19}\right]-\mathrm{MCH}$ in the absence or presence of the test compound in a buffer containing $25 \mathrm{mM}$ Hepes/Tris (pH 7.4), $5 \mathrm{mM}$ $\mathrm{MgCl}_{2}, 1 \mathrm{mM} \mathrm{CaCl}$ and $0.5 \%$ bovine serum albumin. Nonspecific binding is determined in the presence of $0.1 \mu \mathrm{M} \mathrm{MCH}$. Following incubation, the samples are filtered rapidly under vacuum through glass fiber filters (GF/B, Packard) presoaked with $0.5 \%$ BSA and rinsed several times with an ice-cold buffer containing $50 \mathrm{mM}$ Tris- $\mathrm{HCl}(\mathrm{pH} 7.4)$ and $500 \mathrm{mM}$ $\mathrm{NaCl}$ using a 96-sample cell harvester (Unifilter, Packard). The filters are dried and then counted for radioactivity in a scintillation counter (Topcount, Packard) using a scintillation cocktail (Microscint 0, Packard). The results are expressed as percentage inhibition of the control radioligand specific binding. The standard reference compound is $\mathrm{MCH}$, which was tested in each experiment at 8 concentrations to obtain a competition curve from which its $\mathrm{IC}_{50}$ is calculated. The high level of assay robustness and reproducibility of each control monitored over several decades (internal data base, Eurofins) and included in every assay ensure results' reliability even when performed only twice. Experimental points were obtained in two independent measurements, each in duplicate. All data were in less than $5 \%$ variation from each other or they were discarded and re-ran until this variation was reached. Whenever IC50 was concerned, a difference between the two results of more than half a $\log$ invalidates the experiment that will be re-run.

\subsection{MCH Functional Cellular Assay: $\mathrm{MCH}-$ Induced Cytosolic $\mathrm{Ca}^{2+}$ Ion Mobilization}

The functional assay was run onto cells expressing the hMCH-R1 receptor, as described in Wang et al. [61]. In brief, the cells are suspended in DMEM buffer (Invitrogen), then distributed in microplates at a density of 4.104 cells/well. The fluorescent probe (Fluo4 Direct, Invitrogen) mixed with probenecid in Hanks' Balanced Salt solution (HBSS) (Invitrogen) complemented with 20 mM HEPES (Invitrogen) (pH 7.4) is then added into each well and equilibrated with the cells for $60 \mathrm{~min}$ at $37^{\circ} \mathrm{C}$, then $15 \mathrm{~min}$ at $22^{\circ} \mathrm{C}$. Then, the assay plates are positioned in a microplate reader (CellLux, PerkinElmer) which is used 
for the addition of the test compound, reference agonist or HBSS buffer (basal control), and the measurements of changes in fluorescence intensity, which varies proportionally to the free cytosolic $\mathrm{Ca}^{2+}$ ion concentration. For stimulated control measurements, $\mathrm{MCH}$ at $300 \mathrm{nM}$ is added in separate assay wells. The results are expressed as a percentage of the control response to $300 \mathrm{nM} \mathrm{MCH}$. The standard reference agonist is $\mathrm{MCH}$, which is tested in each experiment at several concentrations to generate a concentration-response curve from which its $\mathrm{EC}_{50}$ value is calculated. For the antagonist effect, the results are expressed as a percentage inhibition of the control response to $30 \mathrm{nM} \mathrm{MCH}$, which was added to all tested wells and controls 5 min after the candidate products.

\subsection{Stability of Pseudopeptides, Plasma and Microsomes from Mouse, Rat and Man 4.7.1. Plasma Stability}

Plasmas from 3 species (including commercially available human healthy donors) were adjusted to $\mathrm{pH} 7.4$ if necessary. Incubations were performed at a concentration of $1 \mu \mathrm{M}$ of the compound at $37^{\circ} \mathrm{C}$ (in the presence of a final concentration of DMSO of $2.5 \%$ $v / v$. The incubations were stopped at $0,15,30,60$ and $120 \mathrm{~min}$ by methanol. Each time point was run in sextuplets. The sampling plates were then centrifuged $\left(2500 \mathrm{rpm}, 45 \mathrm{~min}, 4^{\circ} \mathrm{C}\right)$ and the supernatants pooled. Samples were analyzed for parent compound by LC-MS/MS. The percentage of parent compound remaining at each time point relative to the $0 \mathrm{~min}$ sample is then calculated from LC-MS/MS peak area ratios.

\subsubsection{Mouse and Rat Hepatocytes}

The stability of the compound was studied on hepatocyte cultures from Wistar rats and CD1 mice. The compound was incubated at $20 \mu \mathrm{M}$ in the presence of 1.106 cells $/ \mathrm{mL}$ for $5 \mathrm{~h}$. The incubation was then stopped with acetonitrile $(v / v)$ and the supernatant, after a brief centrifugation $\left(2500 \mathrm{rpm}, 5 \mathrm{~min} 4{ }^{\circ} \mathrm{C}\right)$ was submitted to LC-MS analysis, using a THERMO Q Executive coupled to a Waters Acquity UPLC System equipped with a Waters Acquity UPLC C18 $100 \times 2.1 \mathrm{~mm} 1.7 \mu \mathrm{m}$ column.

\subsubsection{Mouse, Rat and Human Hepatic Microsomes}

Metabolic stability was determined at $100 \mathrm{nM}$ on hepatic microsomes from mouse, rat and man $(0.3 \mathrm{mg}$ proteins $/ \mathrm{mL}$ ) from commercial sources. Experiments were performed kinetical, by sampling the medium at the following time points: $0,5,15,30,45 \mathrm{~min}$. The incubation was stopped by mixing the sample $(v / v)$ with pure acetonitrile. Control experiments were run in which NADPH was omitted. All incubations were performed singularly for each test compound but can be reproduced in case of criteria not being fulfilled. LC-MS/MS analysis of these samples will be performed on the most sensitive instrument.

\subsection{Evaluation of Metabolic Stability of the Candidate Pseudopeptides: GPS15290 and GPS18169}

Historically, the first compound in our collection to show interesting characteristics was GPS15290, with a superior affinity at the human receptor and an antagonistic capacity in the high picomolar range. We thus studied its metabolic stability in rats and mice.

Then, the stability in plasma was evaluated by incubating human, rat or mouse plasma with the compound(s) as follows: the product $(0.1 \mu \mathrm{M}$ in TRIS buffer $\mathrm{pH} 7.40 .1 \% \mathrm{BSA})$ was incubated with the plasma at $37^{\circ} \mathrm{C}$. The disappearance of the product was measured at 15, 45, 120, 240 and 300 min by mass spectrometry. Incubations were carried out in a robot Star (Hamilton France, Villebon-sur-Yvette, France). At each sampling time, 50 $\mu \mathrm{L}$ of the reaction medium was removed and diluted with $100 \mu \mathrm{L}$ of acetonitrile. After centrifugation ( $20 \mathrm{~min}$ at $+4{ }^{\circ} \mathrm{C}, 4000 \mathrm{rpm}$ ), $75 \mu \mathrm{L}$ of the supernatants was transferred into a 384 well injection plate. Ten microliters were injected onto UPLC coupled with a XEVO TQS mass spectrometer system (Waters, Milford, MA, USA). The unchanged product is quantified using a reference sample $(0.1 \mu \mathrm{M})$ prepared during the incubation process. A second reference sample at $0.01 \mu \mathrm{M}$ is prepared in the same conditions to verify the linearity 
of the detection method. The peak height (or area) is measured to calculate the half-life of the compound.

\subsection{Diet-Induced Obesity Experiments}

These experiments were performed by Pharmacology Discovery Services Taiwan, Ltd. (New Taipei City, Taiwan), a subsidiary of Eurofins Scientific (Luxembourg, Luxembourg) for the Institut de Recherches Internationales Servier.

\subsubsection{Animals}

Male C57BL/ 6 mice at 4 weeks of age were provided by BioLasco Taiwan (under Charles River Laboratories Licensee). All animals were maintained in an environment with well-controlled temperature $\left(20-24{ }^{\circ} \mathrm{C}\right)$ and humidity (30-70\%) with $12 \mathrm{~h}$ light/dark cycles. Free access to standard lab diet (MFG (Oriental Yeast Co., Ltd., Japan)) and autoclaved tap water was granted. All aspects of this work including housing, experimentation, and animal disposal were performed in general accordance with the "Guide for the Care and Use of Laboratory Animals: Eighth Edition" (National Academies Press, Washington, D.C., 2011) in our laboratory animal facility accredited by the International Council on Accreditation adopted the AVMA Guidelines for the Euthanasia of Animals (AAALAC). In addition, the protocol for animal care and use was reviewed and approved by the Institutional Animal Care and Use Committee (IACUC) at Pharmacology Discovery Services Taiwan, Ltd.

\subsubsection{Origin of Biochemical Tests}

ALT (Alanine aminotransferase) and AST (Aspartate aminotransferase) assay kit (Denka Seiken, Japan), Cholesterol assay kit (Denka, Japan), Creatinine assay kit (Denka Seiken, Japan), Mouse insulin ELISA kit (Crystal chem, Elk Grove Village, IL, USA), $\mathrm{Na}^{+} / \mathrm{K}^{+}$ assay kit (Toshiba, Japan), Triglyceride assay kit (Sentinel Diagnostics, Milano, Italy) and Water for injection (Tai-Yu, Taiwan).

\subsubsection{Diet-induced Obesity Protocol}

The protocol was performed for all groups and all animals. Male C57BL/ 6 mice were fed a high-fat diet (HFD) (60\% of calories) or a standard chow diet (STD) from 4 weeks of age. Thirty (30) mice were fed the HFD and 10 mice were fed the STD (for 8 weeks before treatment) for a total of 20 weeks. The mice assigned to the STD diet were maintained on this diet throughout the study as a reference group of lean control mice. From Week 9, HFD-fed mice were grouped by body weight before dosing. Body weight was recorded three times weekly from Week 9. Food/water intake was recorded twice weekly from Week 9. Blood chemistry analyzes were performed in Weeks 8 (before dosing, Day 56), 16 (Day 113) and 20 (Day 141), including serum insulin, total cholesterol (T-CHO), triglyceride (TG), alanine aminotransferase (ALT), aspartate aminotransferase (AST), uric acid (UA), creatinine, potassium $\left(\mathrm{K}^{+}\right)$and sodium $\left(\mathrm{Na}^{+}\right)$. At the termination in Week 20 (Day 141), the adipose tissue weight, including epididymal, mesenteric, inguinal, retroperitoneal, and brown fat, was measured after the animals were sacrificed. Two-way ANOVA followed by Bonferroni's tests were applied to ascertain the difference between vehicle control and treated animals. Significance was set at $p<0.05$ level. The summary of the treatments is presented in Table 8 . The following parameters were measured: (1) body weight three times weekly; (2) food/water intake twice weekly; (3) blood chemistry in Weeks 8 (before dosing), 16 and 20 including glucose, insulin, serum lipids (triglycerides (TG), total cholesterol (TC), AST, alanine aminotransferase (ALT), uric acid, creatinine, potassium and sodium through 16-h fasting animals; and finally, (4) total body fat (including visceral and subcutaneous fat) in Week 20. 
Table 8. The study design is summarized in the following study design summary table.

\begin{tabular}{|c|c|c|c|c|c|c|}
\hline \multirow{2}{*}{ Group } & \multirow{2}{*}{$\begin{array}{c}\text { Test } \\
\text { Article }\end{array}$} & \multirow{2}{*}{ Route } & \multirow{2}{*}{$\begin{array}{l}\text { Conc. } \\
\mathrm{mg} / \mathrm{ml}\end{array}$} & \multicolumn{2}{|c|}{ Dosage } & \multirow{2}{*}{$\begin{array}{c}\text { Mice } \\
\text { (Male) }\end{array}$} \\
\hline & & & & $\mathrm{mL} / \mathrm{kg}$ & $\mathrm{mg} / \mathrm{kg}$ & \\
\hline 1 & $\begin{array}{c}\text { Vehicle }{ }^{\mathrm{a}, \mathrm{b}} \\
\text { (Normal Diet) }\end{array}$ & IP & NA & 10 & NA, QD x 12 weeks & 10 \\
\hline 2 & $\begin{array}{c}\text { Vehicle }{ }^{a, c} \\
\text { (High-fat diet) }\end{array}$ & IP & NA & 10 & NA, QD x 12 weeks & 10 \\
\hline 3 & GPS18169 a,c & IP & 1 & 10 & 10, QD x 12 weeks & 10 \\
\hline 4 & GPS18169 a,c & IP & 0.5 & 10 & 5, QD x 12 weeks & 10 \\
\hline
\end{tabular}

${ }^{a}$ Water for injection. ${ }^{\mathrm{b}}$ Group 1 mice are placed in a normal diet (MFG) for 8 weeks before treatment. ${ }^{\mathrm{c}}$ Groups $2-4$ mice are placed in a high-fat diet (HFD, $60 \%$ of calories) for 8 weeks before treatment. Test articles and vehicle are administered daily by intraperitoneal injection (IP) for 12 weeks after 8 weeks of HFD feeding.

Supplementary Materials: The following are available online, Table S1: Characteristics of the peptides and pseudopeptides synthesized for the present study; Table S2: Blood biochemistry of dietinduced obese mice with and without treatment by the MCH-R1 antagonist GPS18169. Individual data; Table S3: Comparison of the adipose tissue weights between lean, high fat diet fed and GPS18169-treated mice. Individual data. Table S4: Food intake in high-fat diet-induced obesity model in C57BL/ 6 mice during treatment with GPS18169. Individual data. Table S5: Water intake in high-fat diet-induced obesity model in C57BL/ 6 mice during treatment with GPS18169. Individual data. Table S6: Body weight changes in high-fat diet-induced obesity model in C57Bl/6 mice during treatment with GPS18169. Individual data.

Author Contributions: Conceptualization, J.A.B., K.P., L.F., G.F., P.G., L.R.; methodology, M.J., P.D., A.P., A.K., M.G., T.L.D. and M.B.; validation, K.P., J.A.B., T.L.D., M.B., P.D. and A.K.; writing—original draft preparation, J.A.B., M.J., L.F. T.L.D., L.R.; writing-review and editing, J.A.B., M.B. and P.D.; supervision, J.A.B., G.F., K.P. and P.G.; project administration, G.F. and K.P. All authors have read and agreed to the published version of the manuscript.

Funding: This research received no external funding.

Institutional Review Board Statement: The protocol for animal care and use was reviewed and approved by the IACUC at Pharmacology Discovery Services Taiwan, Ltd.

Data Availability Statement: All the individual data are gathered in the Supplemental material section.

Conflicts of Interest: The authors declare no conflict of interest.

Sample Availability: Compounds are available from Genepep SAS.

\section{References}

1. Swinburn, B.A.; Sacks, G.; Hall, K.D.; McPherson, K.; Finegood, D.T.; Moodie, M.L.; Gortmaker, S.L. The global obesity pandemic: Shaped by global drivers and local environments. Lancet 2011, 378, 804-814. [CrossRef]

2. García-García, F.J; Monistrol-Mula, A.; Cardellach, F.; Garrabou, G. Nutrition, Bioenergetics, and Metabolic Syndrome. Nutrients 2020, 12, 2785. [CrossRef]

3. Byaruhanga, J.; Atorkey, P.; McLaughlin, M.; Brown, A.; Byrnes, E.; Paul, C.; Wiggers, J.; Tzelepis, F. Effectiveness of Individual Real-Time Video Counseling on Smoking, Nutrition, Alcohol, Physical Activity, and Obesity Health Risks: Systematic Review. J. Med. Internet Res. 2020, 22, e18621. [CrossRef]

4. Oh, T.J. The Role of Anti-Obesity Medication in Prevention of Diabetes and Its Complications. J. Obes. Metab. Syndr. 2019, 28, 158-166. [CrossRef] [PubMed]

5. Peres, K.C.; Riera, R.; Martimbianco, A.L.C.; Ward, L.S.; Cunha, L.L. Body Mass Index and Prognosis of COVID-19 Infection. A Systematic Review. Front. Endocrinol. 2020, 11, 562. [CrossRef]

6. Della-Zuana, O.; Presse, F.; Ortola, C.; Duhault, J.; Nahon, J.-L.; Levens, N. Acute and chronic administration of melaninconcentrating hormone enhances food intake and body weight in Wistar and Sprague-Dawley rats. Int. J. Obes. Relat. Metab. Disord. 2002, 26, 1289-1295. [CrossRef] [PubMed]

7. Cardinaud, B.; Darré-Toulemonde, F.; Duhault, J.; Boutin, J.A.; Nahon, J.-L. Comparative analysis of melanin-concentrating hormone structure and activity in fishes and mammals. Peptides 2004, 25, 1623-1632. [CrossRef] [PubMed]

8. Diniz, G.B.; Bittencourt, J.C. The Melanin-Concentrating Hormone (MCH) System: A Tale of Two Peptides. Front. Neurosci. 2019, 13, 1280. [CrossRef] 
9. Audinot, V.; Boutin, J.A.; Lakaye, B.; Nahon, J.-L.; Saito, Y. Melanin-concentrating hormone receptors (version 2019.4) in the IUPHAR/BPS Guide to Pharmacology Database. GtoPdb CITE 2019, 2019. [CrossRef]

10. Kokkotou, E.; Jeon, J.Y.; Wang, X.; Marino, F.E.; Carlson, M.; Trombly, D.J.; Maratos-Flier, E. Mice with MCH ablation resist diet-induced obesity through strain-specific mechanisms. Am. J. Physiol. Regul. Integr. Comp. Physiol. 2005, 289, R117-R124. [CrossRef] [PubMed]

11. Gomori, A.; Ishihara, A.; Ito, M.; Matsushita, H.; Mashiko, S.; Iwaasa, H.; Matsuda, M.; Bednarek, M.A.; Qian, S.; Macneil, D.J.; et al. Blockade of $\mathrm{MCH} 1$ receptor signalling ameliorates obesity and related hepatic steatosis in ovariectomized mice. Br. J. Pharmacol. 2007, 151, 900-908. [CrossRef]

12. Marsh, D.J.; Weingarth, D.T.; Novi, D.E.; Chen, H.Y.; Trumbauer, M.E.; Chen, A.S.; Guan, X.-M.; Jiang, M.M.; Feng, Y.; Camacho, R.E.; et al. Melanin-concentrating hormone 1 receptor-deficient mice are lean, hyperactive, and hyperphagic and have altered metabolism. Proc. Natl. Acad. Sci. USA 2002, 99, 3240-3245. [CrossRef]

13. Vaisse, C.; Reiter, J.F.; Berbari, N.F. Cilia and Obesity. Cold Spring Harb. Perspect. Biol. 2017, 9, a028217. [CrossRef]

14. Miki, D.; Kobayashi, Y.; Okada, T.; Miyamoto, T.; Takei, N.; Sekino, Y.; Koganezawa, N.; Shirao, T.; Saito, Y. Characterization of Functional Primary Cilia in Human Induced Pluripotent Stem Cell-Derived Neurons. Neurochem. Res. 2019, 44, 1736-1744. [CrossRef]

15. Morganstern, I.; Gulati, G.; Leibowitz, S.F. Role of melanin-concentrating hormone in drug use disorders. Brain Res. 2020, 1741, 146872. [CrossRef]

16. Oh, S.T.; Liu, Q.F.; Jeong, H.J.; Lee, S.; Samidurai, M.; Jo, J.; Pak, S.C.; Park, H.-J.; Kim, J.; Jeon, S. Nasal Cavity Administration of Melanin-Concentrating Hormone Improves Memory Impairment in Memory-Impaired and Alzheimer's Disease Mouse Models. Mol. Neurobiol. 2019, 56, 8076-8086. [CrossRef] [PubMed]

17. Ye, H.; Cui, X.-Y.; Ding, H.; Cui, S.-Y.; Hu, X.; Liu, Y.-T.; Zhao, H.-L.; Zhang, Y.-H. Melanin-Concentrating Hormone (MCH) and $\mathrm{MCH}-\mathrm{R} 1$ in the Locus Coeruleus May Be Involved in the Regulation of Depressive-Like Behavior. Int. J. Neuropsychopharmacol. 2018, 21, 1128-1137. [CrossRef]

18. Bandaru, S.S.; Khanday, M.A.; Ibrahim, N.; Naganuma, F.; Vetrivelan, R. Sleep-Wake Control by Melanin-Concentrating Hormone $(\mathrm{MCH})$ Neurons: A Review of Recent Findings. Curr. Neurol. Neurosci. Rep. 2020, 20, 55. [CrossRef] [PubMed]

19. Chee, M.J.; Hebert, A.J.; Briançon, N.; Flaherty, S.E.; Pissios, P.; Maratos-Flier, E. Conditional deletion of melanin-concentrating hormone receptor 1 from GABAergic neurons increases locomotor activity. Mol. Metab. 2019, 29, 114-123. [CrossRef] [PubMed]

20. Tavares, F.X.; Al-Barazanji, K.A.; Bigham, E.C.; Bishop, M.J.; Britt, C.S.; Carlton, D.L.; Feldman, P.L.; Goetz, A.S.; Grizzle, M.K.; Guo, Y.C.; et al. Potent, Selective, and Orally Efficacious Antagonists of Melanin-Concentrating Hormone Receptor 1. J. Med. Chem. 2006, 49, 7095-7107. [CrossRef]

21. Johansson, A.; Löfberg, C.; Antonsson, M.; Von Unge, S.; Hayes, M.A.; Judkins, R.; Ploj, K.; Benthem, L.; Lindén, D.; Brodin, P.; et al. Discovery of (3-(4-(2-Oxa-6-azaspiro3.3heptan-6-ylmethyl)phenoxy)azetidin-1-yl)(5-(4-methoxyphenyl)-1,3,4-oxadiazol-2yl)methanone (AZD1979), a Melanin Concentrating Hormone Receptor 1 (MCHr1) Antagonist with Favorable Physicochemical Properties. J. Med. Chem. 2016, 59, 2497-2511. [CrossRef]

22. Yan, J.-H.; Li, Q.-Y.; Boutin, J.A.; Renard, M.P.; Ding, Y.-X.; Hao, X.-J.; Zhao, W.-M.; Wang, M.-W. High-throughput screening of novel antagonists on melanin-concentrating hormone receptor-1. Acta Pharmacol. Sin. 2008, 29, 752-758. [CrossRef]

23. Berglund, S.; Egner, B.J.; Gradén, H.; Gradén, J.; Morgan, D.G.; Inghardt, T.; Giordanetto, F. Optimization of piperidin-4-yl-ureacontaining melanin-concentrating hormone receptor 1 (MCH-R1) antagonists: Reducing hERG-associated liabilities. Bioorganic Med. Chem. Lett. 2009, 19, 4274-4279. [CrossRef] [PubMed]

24. Johansson, A. Recent progress in the discovery of melanin-concentrating hormone 1-receptor antagonists. Expert Opin. Ther. Patents 2011, 21, 905-925. [CrossRef]

25. Naganuma, F.; Bandaru, S.S.; Absi, G.; Mahoney, C.E.; Scammell, T.E.; Vetrivelan, R. Melanin-concentrating hormone neurons contribute to dysregulation of rapid eye movement sleep in narcolepsy. Neurobiol. Dis. 2018, 120, 12-20. [CrossRef] [PubMed]

26. Audinot, V.; Beauverger, P.; Lahaye, C.; Suply, T.; Rodriguez, M.; Ouvry, C.; Lamamy, V.; Imbert, J.; Rique, H.; Nahon, J.-L.; et al. Structure-Activity Relationship Studies of Melanin-concentrating Hormone (MCH)-related Peptide Ligands at SLC-1, the Human MCH Receptor. J. Biol. Chem. 2001, 276, 13554-13562. [CrossRef]

27. Audinot, V.; Lahaye, C.; Suply, T.; Beauverger, P.; Rodriguez, M.; Galizzi, J.-P.; Fauchère, J.-L.; A Boutin, J.A. 125 I-S36057: A new and highly potent radioligand for the melanin-concentrating hormone receptor. Br. J. Pharmacol. 2001, 133, 371-378. [CrossRef]

28. Audinot, V.; Della Zuana, O.; Fabry, N.; Ouvry, C.; Nosjean, O.; Henlin, J.-M.; Fauchère, J.-L.; Boutin, J.A. S38151 pguanidinobenzoyl-Des-Gly(10)-MCH(7-17) is a potent and selective antagonist at the $\mathrm{MCH}(1)$ receptor and has an-ti-feeding properties in vivo. Peptides 2009, 30, 1997-2007. [CrossRef]

29. Della-Zuana, O.; Audinot, V.; Levenez, V.; Ktorza, A.; Presse, F.; Nahon, J.-L.; Boutin, J.A. Peripheral injections of melaninconcentrating hormone receptor 1 antagonist S38151 decrease food intake and body weight in rodent obesity models. Front. Endocrinol. 2012, 3, 160. [CrossRef] [PubMed]

30. Molek, P.; Strukelj, B.; Bratkovic, T. Peptide Phage Display as a Tool for Drug Discovery: Targeting Membrane Receptors. Molecules 2011, 16, 857-887. [CrossRef]

31. Joo, S.-H. Cyclic Peptides as Therapeutic Agents and Biochemical Tools. Biomol. Ther. 2012, 20, 19-26. [CrossRef]

32. Lau, J.L.; Dunn, M.K. Therapeutic peptides: Historical perspectives, current development trends, and future directions. Bioorganic Med. Chem. 2018, 26, 2700-2707. [CrossRef] 
33. Lee, A.C.-L.; Harris, J.L.; Khanna, K.K.; Hong, J.-H. A Comprehensive Review on Current Advances in Peptide Drug Development and Design. Int. J. Mol. Sci. 2019, 20, 2383. [CrossRef] [PubMed]

34. Fosgerau, K.; Hoffmann, T. Peptide therapeutics: Current status and future directions. Drug Discov. Today 2015, 20, 122-128. [CrossRef] [PubMed]

35. Boutin, J.A.; Tartar, A.L.; Van Dorsselaer, A.; Vaudry, H. General lack of structural characterization of chemically synthesized long peptides. Protein Sci. 2019, 28, 857-867. [CrossRef]

36. Kenakin, T. A Scale of Agonism and Allosteric Modulation for Assessment of Selectivity, Bias, and Receptor Mutation. Mol. Pharmacol. 2017, 92, 414-424. [CrossRef]

37. Boutin, J.A.; Legros, C. The five dimensions of receptor pharmacology exemplified by melatonin receptors: An opinion. Pharmacol. Res. Perspect. 2020, 8, e00556. [CrossRef]

38. Legros, C.; Dupré, C.; Brasseur, C.; Bonnaud, A.; Bruno, O.; Valour, D.; Shabajee, P.; Giganti, A.; Nosjean, O.; Kenakin, T.P.; et al. Characterization of the various functional pathways elicited by synthetic agonists or antagonists at the melatonin MT 1 and MT 2 receptors. Pharmacol. Res. Perspect. 2020, 8, e00539. [CrossRef]

39. Chaki, S.; Shimazaki, T.; Nishiguchi, M.; Funakoshi, T.; Iijima, M.; Ito, A.; Kanuma, K.; Sekiguchi, Y. Antidepressant/anxiolytic potential and adverse effect liabilities of melanin-concentrating hormone receptor 1 antagonists in animal models. Pharmacol. Biochem. Behav. 2015, 135, 154-168. [CrossRef] [PubMed]

40. Chaki, S.; Funakoshi, T.; Hirota-Okuno, S.; Nishiguchi, M.; Shimazaki, T.; Iijima, M.; Grottick, A.J.; Kanuma, K.; Omodera, K.; Sekiguchi, Y.; et al. Anxiolytic- and Antidepressant-Like Profile of ATC0065 and ATC0175: Nonpeptidic and Orally Active Melanin-Concentrating Hormone Receptor 1 Antagonists. J. Pharmacol. Exp. Ther. 2005, 313, 831-839. [CrossRef] [PubMed]

41. Cippitelli, A.; Karlsson, C.; Shaw, J.L.; Thorsell, A.; Gehlert, D.R.; Heilig, M. Suppression of alcohol self-administration and reinstatement of alcohol seeking by melanin-concentrating hormone receptor 1 (MCH1-R) antagonism in Wistar rats. Psychopharmacology 2010, 211, 367-375. [CrossRef]

42. Borowsky, B.; Durkin, M.M.; Ogozalek, K.; Marzabadi, M.R.; DeLeon, J.; Lagu, B.; Heurich, R.; Lichtblau, H.; Shaposhnik, Z.; Daniewska, I.; et al. Antidepressant, anxiolytic and anorectic effects of a melanin-concentrating hormone-1 receptor antagonist. Nat. Med. 2002, 8, 825-830. [CrossRef] [PubMed]

43. Åstrand, A.; Bohlooly, M.-Y.; Larsdotter, S.; Mahlapuu, M.; Andersén, H.; Tornell, J.; Ohlsson, C.; Snaith, M.; Morgan, D.G.A. Mice lacking melanin-concentrating hormone receptor 1 demonstrate increased heart rate associated with altered autonomic activity. Am. J. Physiol. Regul. Integr. Comp. Physiol. 2004, 287, R749-R758. [CrossRef]

44. García-Fuster, M.J.; Parks, G.S.; Clinton, S.M.; Watson, S.J.; Akil, H.; Civelli, O. The melanin-concentrating hormone (MCH) system in an animal model of depression-like behavior. Eur. Neuropsychopharmacol. 2012, 22, 607-613. [CrossRef] [PubMed]

45. Kühnen, P.; Wiegand, S.; Biebermann, H. Pharmacological treatment strategies for patients with monogenic obesity. J. Pediatr. Endocrinol. Metab. 2020, 33, 967-973. [CrossRef] [PubMed]

46. Zachurzok, A.; Ranke, M.B.; Flehmig, B.; Jakubek-Kipa, K.; Marcinkiewicz, K.; Mazur, A.; Petriczko, E.; Pridzun, L.; Von Schnurbein, J.; Walczak, M.; et al. Relative leptin deficiency in children with severe early-onset obesity (SEOO)—Results of the Early-onset Obesity and Leptin-German-Polish Study (EOL-GPS). J. Pediatr. Endocrinol. Metab. 2020, 33, 255-263. [CrossRef]

47. Adrian, S.; Miao, H.; Feng, H.; Scherzinger, A.; Nardini, G.; Beghetto, B.; Roncaglia, E.; Ligabue, G.; Milic, J.; Guaraldi, G.; et al. Effects of atazanavir, darunavir, and raltegravir on fat and muscle among persons living with HIV. HIV Res. Clin. Pr. 2020, 21, 1-8. [CrossRef] [PubMed]

48. Rothwell, N.J.; Stock, M.J. Regulation of energy balance in two models of reversible obesity in the rat. J. Comp. Physiol. Psychol. 1979, 93, 1024-1034. [CrossRef]

49. Adlercreutz, H. Western diet and Western diseases: Some hormonal and biochemical mechanisms and associations. Scand. J. Clin. Lab. Investig. Suppl. 1990, 201, 3-23. [CrossRef]

50. Wang, C.-Y.; Liao, J.K. A Mouse Model of Diet-Induced Obesity and Insulin Resistance. Methods Mol. Biol. 2012, 821, 421-433. [CrossRef]

51. Lang, P.; Hasselwander, S.; Li, H.; Xia, N. Effects of different diets used in diet-induced obesity models on insulin resistance and vascular dysfunction in C57BL/6 mice. Sci. Rep. 2019, 9, 19556. [CrossRef]

52. Jaacks, L.M.; Vandevijvere, S.; Pan, A.; McGowan, C.J.; Wallace, C.; Imamura, F.; Mozaffarian, D.; Swinburn, B.; Ezzati, M. The obesity transition: Stages of the global epidemic. Lancet Diabetes Endocrinol. 2019, 7, 231-240. [CrossRef]

53. Kleine, C.-E.; Moradi, H.; Streja, E.; Kalantar-Zadeh, K. Racial and Ethnic Disparities in the Obesity Paradox. Am. J. Kidney Dis. 2018, 72, S26-S32. [CrossRef]

54. Morley, J.E.; Levine, A.S.; Murray, S.S.; Kneip, J.; Grace, M. Peptidergic regulation of stress-induced eating. Am. J. Physiol. 1982, 243, R159-R163. [CrossRef] [PubMed]

55. Rodriguez, M.; Audinot, V.; Dromaint, S.; Macia, C.; Lamamy, V.; Beauverger, P.; Rique, H.; Imbert, J.; Nicolas, J.P.; Boutin, J.A.; et al. Molecular identification of the long isoform of the human neuropeptide Y Y5 receptor and pharmacological comparison with the short Y5 receptor isoform. Biochem. J. 2003, 369, 667-673. [CrossRef] [PubMed]

56. Bradley, R.L.; Kokkotou, E.G.; Maratos-Flier, E.; Cheatham, B. Melanin-concentrating hormone regulates leptin synthesis and secretion in rat adipocytes. Diabetes 2000, 49, 1073-1077. [CrossRef] [PubMed]

57. Bockus, A.T.; McEwen, C.M.; Lokey, R.S. Form and Function in Cyclic Peptide Natural Products: A Pharmacokinetic Perspective. Curr. Top. Med. Chem. 2013, 13, 821-836. [CrossRef] 
58. Lizcano, F.; Arroyave, F. Control of Adipose Cell Browning and Its Therapeutic Potential. Metabolites 2020, 10, 471. [CrossRef] [PubMed]

59. Li, V.L.; Kim, J.T.; Long, J.Z. Adipose Tissue Lipokines: Recent Progress and Future Directions. Diabetes 2020, 69, 2541-2548. [CrossRef]

60. Macdonald, D.; Murgolo, N.; Zhang, R.; Durkin, J.P.; Yao, X.; Strader, C.D.; Graziano, M.P. Molecular Characterization of the Melanin-Concentrating Hormone/Receptor Complex: Identification of Critical Residues Involved in Binding and Activation. Mol. Pharmacol. 2000, 58, 217-225. [CrossRef]

61. Wang, S.; Behan, J.; O’Neill, K.; Weig, B.; Fried, S.; Laz, T.; Bayne, M.; Gustafson, E.; Hawes, B.E. Identification and Pharmacological Characterization of a Novel Human Melanin-concentrating Hormone Receptor, mch-r2. J. Biol. Chem. 2001, 276, 34664-34670. [CrossRef] [PubMed] 